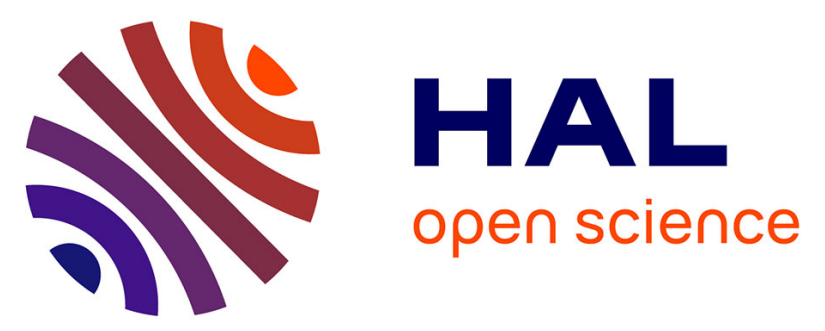

\title{
A geochemical and multi-isotope modeling approach to determine sources and fate of methane in shallow groundwater above unconventional hydrocarbon reservoirs
}

Pauline Humez, Florian Osselin, Wolfram Kloppmann, Bernhard Mayer

\section{To cite this version:}

Pauline Humez, Florian Osselin, Wolfram Kloppmann, Bernhard Mayer. A geochemical and multiisotope modeling approach to determine sources and fate of methane in shallow groundwater above unconventional hydrocarbon reservoirs. Journal of Contaminant Hydrology, 2019, 226, 103525 (13 p.). 10.1016/j.jconhyd.2019.103525 . insu-02262285

\section{HAL Id: insu-02262285 \\ https://hal-insu.archives-ouvertes.fr/insu-02262285}

Submitted on 2 Aug 2019

HAL is a multi-disciplinary open access archive for the deposit and dissemination of scientific research documents, whether they are published or not. The documents may come from teaching and research institutions in France or abroad, or from public or private research centers.
L'archive ouverte pluridisciplinaire HAL, est destinée au dépôt et à la diffusion de documents scientifiques de niveau recherche, publiés ou non, émanant des établissements d'enseignement et de recherche français ou étrangers, des laboratoires publics ou privés. 


\section{Accepted Manuscript}

A geochemical and multi-isotope modeling approach to determine sources and fate of methane in shallow groundwater above unconventional hydrocarbon reservoirs

Pauline Humez, Florian Osselin, Wolfram Kloppmann, Bernhard Mayer

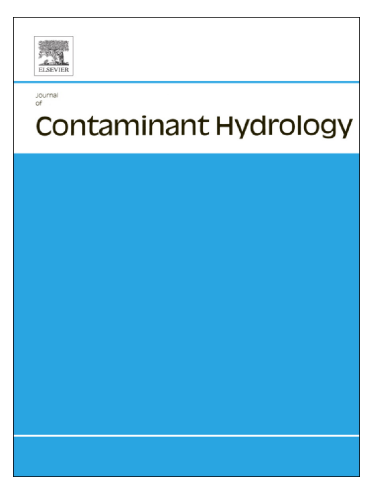

PII: S0169-7722(19)30006-3

DOI: https://doi.org/10.1016/j.jconhyd.2019.103525

Article Number: 103525

Reference: CONHYD 103525

To appear in: Journal of Contaminant Hydrology

Received date: 7 January 2019

Revised date: 12 July 2019

Accepted date: 19 July 2019

Please cite this article as: P. Humez, F. Osselin, W. Kloppmann, et al., A geochemical and multi-isotope modeling approach to determine sources and fate of methane in shallow groundwater above unconventional hydrocarbon reservoirs, Journal of Contaminant Hydrology, https://doi.org/10.1016/j.jconhyd.2019.103525

This is a PDF file of an unedited manuscript that has been accepted for publication. As a service to our customers we are providing this early version of the manuscript. The manuscript will undergo copyediting, typesetting, and review of the resulting proof before it is published in its final form. Please note that during the production process errors may be discovered which could affect the content, and all legal disclaimers that apply to the journal pertain. 
A geochemical and multi-isotope modeling approach to determine sources and fate of methane in shallow groundwater above unconventional hydrocarbon reservoirs

Pauline Humez ${ }^{1, *}$ phumez@ucalgary.ca, Florian Osselin ${ }^{1,2}$, Wolfram Kloppmann ${ }^{3}$ and Bernhard Mayer $^{1}$

${ }^{1}$ Applied Geochemistry Group, Department of Geoscience, University of Calgary, 2500

University Dr. NW, Calgary, Alberta, Canada T2N 1N4

${ }^{2}$ Earth Sciences Institute of Orleans (ISTO), University of Orléans, Orléans, France

${ }^{3}$ French Geological Survey (BRGM), Orléans, France

${ }^{*}$ Corresponding author.

\begin{abstract}
Due to increasing concerns over the potential impact of shale gas and coalbed methane (CBM) development on groundwater resources, it has become necessary to develop reliable tools to detect any potential pollution associated with hydrocarbon exploitation from unconventional reservoirs. One of the key concepts for such monitoring approaches is the establishment of a geochemical baseline of the considered groundwater systems. However, the detection of methane is not enough to assess potential impact from CBM and shale gas exploitation since methane in low concentrations has been found to be naturally ubiquitous in many groundwater systems. The objective of this study was to determine the methane sources, the extent of potential methane oxidation, and gas-water-rock-interactions in shallow aquifers by integrating chemical and isotopic monitoring data of dissolved gases and aqueous species into a geochemical PHREEQC model. Using data from a regional groundwater observation network in Alberta (Canada), the model was designed to describe the evolution of the concentrations of methane, sulfate and dissolved inorganic carbon (DIC) as well as their isotopic compositions $\left(\delta^{34} \mathrm{~S}_{\mathrm{SO} 4}, \delta^{13} \mathrm{C}_{\mathrm{CH} 4}\right.$ and $\delta^{13} \mathrm{C}_{\mathrm{DIC}}$ ) in groundwater subjected to different scenarios of migration, oxidation and in situ generation of methane. Model results show that methane migration and subsequent methane oxidation in anaerobic environments can strongly affect its concentration and isotopic fingerprint and potentially compromise the accurate identification of the methane source. For example elevated $\delta^{13} \mathrm{C}_{\mathrm{CH} 4}$ values can be the result of oxidation of microbial methane and may be
\end{abstract}


misinterpreted as methane of thermogenic origin. Hence, quantification of the extent of methane oxidation is essential for determining the origin of methane in groundwater. The application of this model to aquifers in Alberta shows that some cases of elevated $\delta^{13} \mathrm{C}_{\mathrm{CH} 4}$ values were due to methane oxidation resulting in pseudo-thermogenic isotopic fingerprints of methane. The model indicated no contamination of shallow aquifers by deep thermogenic methane from conventional and unconventional hydrocarbon reservoirs under baseline conditions. The developed geochemical and multi-isotopic model describing the sources and fate of methane in groundwater is a promising tool for groundwater assessment purposes in areas with shale gas and coalbed methane development.

\section{Keywords}

Methane; groundwater; stable isotope ratios; geochemical modelling; shale gas; coalbed methane

\section{Introduction}

The recent expansion of the natural gas and oil industry into unconventional hydrocarbon reservoirs in North America and other parts of the world (e.g. Argentina, Poland, Russia) is currently transforming the global energy outlook (US EIA, 2015; US EIA, 2016). Shale gas exploitation has increased markedly in the past decade due to horizontal drilling and hydraulic fracturing which have allowed the exploitation of hydrocarbon resources trapped in very low permeability source rocks. The production of these resources, however, is often associated with environmental concerns regarding freshwater consumption and potential contamination of surface water and groundwater, the appropriate management and treatment of fracturing chemicals and produced fluids, as well as other issues including induced seismicity, noise, traffic, air quality and atmospheric emissions (e.g. Rivard et al., 2014).

One of the main concerns is the potential migration of natural gas (composed mostly of methane, $\mathrm{CH}_{4}$ ) toward freshwater resources (e.g. Jasechko and Perrone, 2017; Lefebvre 2017; Rice et al., 2018; Bachu, 2017; Cahill et al, 2017; DiGiulio and Jackson, 2016; Harkness et al., 2017; Nicot et al., 2017; Wolfe and Wilkin, 2017). According to the terminology of Milkov and Etiope (2018), methane in natural environments can have biotic or abiotic origins. Biotic $\mathrm{CH}_{4}$ is derived from biologically produced organic matter while the numerous reaction pathways resulting in abiotic methane production from geological sources are gaining increasing attention (Sherwood Lollar et al., 1993; Glasby, 2006; Etiope \& Sherwood Lollar, 2013; Etiope \& Schoell, 2014). 
Biotic $\mathrm{CH}_{4}$ is produced either by microbial or thermogenic degradation of organic matter. Microbial $\mathrm{CH}_{4}$ (also often called biogenic) is formed in relatively shallow geological formations through the microorganism-mediated decomposition of organic matter via acetate fermentation or reduction of $\mathrm{CO}_{2}$. Thermogenic gas is generated by degradation reactions of organic matter in deeper geological formations under high pressure and temperature (Whiticar, 1999; Schoell, 1980; Schoell, 1983).

Different classification schemes and plots (Bernard et al., 1976; Bernard et al., 1977; Schoell, 1980; Schoell, 1983;Whiticar \& Faber, 1986) recently revised by Milkov and Etiope (2018) have been used to distinguish microbial gases from thermogenic gases even though post-genetic reactions may alter the initial chemical or isotopic signature of methane and higher alkanes. Natural gas of primary microbial origin usually contains at most trace amounts $(<0.05 \%)$ of higher alkanes $\left(\mathrm{C}_{2+}\right)$ such as ethane resulting in a dryness parameter $\left(\mathrm{CH}_{4} /\left(\sum \mathrm{C}_{2+}\right)\right.$ higher than 1000 (Bernard et al., 1977) although dryness ratios as low as 100 for microbial gases have been reported more recently (Milkov and Etiope, 2018). Additionally, microbial gas has usually carbon isotope ratios of methane expressed as $\delta^{13} \mathrm{C}_{\mathrm{CH} 4}$ (in \%ovs. the standard V-PDB) ranging from -120 $\%$ to a traditional upper limit of $-60 \%$ (Schoell, 1983) that was recently revised to a higher value of $-50 \%$ (Milkov and Etiope, 2018). Thermogenic natural gas typically contains $>2 \% \mathrm{C}_{2+}$ alkanes resulting in a dryness parameter of $\left\langle 500\right.$, and is usually characterized by $\delta^{13} \mathrm{C}_{\mathrm{CH} 4}$ values $>$ $-55 \%$ (Schoell, 1983) although more negative $\delta^{13} \mathrm{C}$ values for immature thermogenic methane have been reported (Rowe and Muehlenbachs, 1999; Tilley and Muehlenbachs, 2011; Milkov and Etiope, 2018). Milkov and Etiope (2018) revised and enlarged the thermogenic gas field compared to the original diagrams of Bernard et al. $(1976,1977)$ and Schoell $(1983)$ with overall $\delta^{13} \mathrm{C}$ values for thermogenic methane from $-20 \%$ to $-73 \%$, and the range of -55 to $-73 \%$ o characterizing early mature thermogenic gases (also referred to as immature gas). Such $\delta^{13} \mathrm{C}$ values for early mature thermogenic gas could be misinterpreted as pure microbial gases but may also constitute a mixture between microbial and thermogenic gas (Milkov and Etiope, 2018).

These chemical and isotopic properties of microbial and thermogenic gas form the basis for identifying the sources of methane in shallow environments and in particular shallow groundwaters. Many groundwater monitoring programs mandated by various states in the USA and provinces in Canada rely on these fundamental characteristics to differentiate microbial methane that may have formed in shallow environments from thermogenic fugitive methane. The 
latter may potentially migrate either from the intermediate depth zone below the base of groundwater protection (BGP, Lemay 2008), or from deep hydrocarbon production zones.

However, chemical and isotopic fractionation occurring during gas migration and methane oxidation may hinder the isotopic and compositional identification of gas sources (e.g. Etiope, 2015; Prinzhofer and Pernaton, 1997). Solubilities of methane, ethane, and higher alkanes vary as a function of pressure and temperature (Culberson, McKetta, 1951; IUPAC-NIST, 2012). During the migration of fluids from hydrocarbon reservoirs at depths between 2 and $4 \mathrm{~km}$, towards the Earth' surface, alkanes will exsolve into a free gas phase at different rates causing changes in the dryness parameter (McAuliffe, 1963), a process often referred to as solubility fractionation (McIntosh et al., 2018; Milkov and Etiope, 2018). Some studies have reported ${ }^{12} \mathrm{C}$ enrichment due to diffusive migration effects in coal leading to more negative $\delta^{13} \mathrm{C}_{\mathrm{CH} 4}$ values in diffused $\mathrm{CH}_{4}$ compared to its source (Prinzhofer and Huc, 1995; Prinzhofer and Pernaton, 1997). In addition, methane may undergo partial oxidation under aerobic (coupled with $\mathrm{O}_{2}$ reduction) or anaerobic conditions (e.g. coupled with denitrification or bacterial sulfate reduction). During oxidation, the light isotopes ${ }^{12} \mathrm{C}$ and ${ }^{1} \mathrm{H}$ are preferentially metabolized, leaving the remaining methane enriched in ${ }^{13} \mathrm{C}$ and ${ }^{2} \mathrm{H}$ resulting in elevated $\delta^{13} \mathrm{C}$ and $\delta^{2} \mathrm{H}$ values in the remaining methane (Whiticar and Faber, 1986; Barker and Fritz, 1981). In consequence, it is possible to find microbial but partially oxidized methane with $\delta^{13} \mathrm{C}$ values between -50 and $-30 \%$, i.e. in the range of thermogenic methane. Such elevated $\delta^{13} \mathrm{C}$ values of microbial methane that has undergone partial oxidation is referred to as pseudo-thermogenic. These processes may hinder the accurate differentiation of thermogenic and microbial methane leading potentially to false claims of thermogenic gas occurrence in shallow environments, if the assessment relies on the interpretation of gas composition and gas isotope ratios alone (Rice et al., 2018).

It is therefore essential to develop reliable approaches to differentiate truly thermogenic gases from pseudo-thermogenic methane, namely microbial methane that has undergone oxidation, to accurately detect migration of methane from deep geological strata into shallow aquifers. The incorporation of other aqueous species and their isotopic fingerprints such as dissolved inorganic carbon (DIC), sulfate, and nitrate (if present) in such an approach can reveal processes such as denitrification and bacterial sulfate reduction coupled with anaerobic or aerobic oxidation of methane impacting the concentrations and carbon isotope ratios of DIC and methane.

Determining concentration and isotope ratios for the relevant dissolved and gaseous compounds and subsequent joint interpretation of the results is therefore a highly promising approach to 
assess whether methane in groundwater has been affected by geochemical processes modifying its isotopic composition. The often complex and challenging interpretation of such data sets can be facilitated by the use of geochemical modeling programs. One of the most widely used thermo-kinetic codes is PHREEQC, developed by the US Geological Survey (USGS), able to simulate geochemical reactions between water, gas, and mineral phases in aqueous systems (Parkhurst and Appelo, 2009). Hence, PHREEQC could be a powerful tool for the quantitative assessment of the sequence and the extent of biogeochemical reactions potentially affecting the chemical and isotopic fingerprints of methane, provided that the associated isotope fractionations factors are taken into account. In this case, inverse geochemical modeling of aerobic or anaerobic methane oxidation processes would allow backtracking to the original sources and concentrations of methane in shallow groundwater.

The objective of this study was to develop a method for accurately determining the origin and fate of methane in groundwater by integrating chemical and isotopic monitoring data of dissolved gases and aqueous species into a stringent geochemical model. A multi-isotope PHREEQC module was written for this study and tested on a groundwater data set from aquifers in Alberta, Canada. The module describes generic concepts controlling methanogenesis and methane oxidation that can be transferred to other groundwater study sites, associated with coalbed methane and shale gas development.

\section{Shallow aquifers in Alberta}

Alberta is Canada's most important oil and natural gas producing province with large conventional and unconventional hydrocarbon reserves. The latter include crude bitumen in northern Alberta, shale gas and tight gas ${ }^{1}$ in the northwest, and coal bed methane (CBM) in southcentral Alberta (AER, 2014). Since the exploitation of these resources is often associated with environmental concerns regarding water consumption and potential contamination of shallow aquifers, groundwater monitoring programs have been put into place to detect potential adverse impacts from resource development, initially implemented during the phase of rapid development of unconventional energy resources accessing coal bed methane (CBM) (e.g. AER Directive 35). In the area that was targeted for CBM production, the Government of Alberta maintains a number of monitoring wells belonging to the provincial Groundwater Observation Well Network

${ }^{1}$ defined as low permeability non-shalegas reserves by AER (2015) 
(GOWN) that is comprised of monitoring wells completed in various shallow aquifers throughout the province that are usually screened only in a single formation. The GOWN consists currently of over 250 active observation wells with most of them located in CBM production areas in the southeastern part of the province, while only a few GOWN wells exist in the regions with shale gas development in the northwest. A comprehensive monitoring program conducted since 2006 has collected water levels and chemical and isotopic water quality information for aqueous samples and dissolved and free gases from, on average, 60 monitoring wells per year (Humez et al., 2016a; Humez et al., 2016b).

For this study, we selected 21 GOWN wells that were repeatedly (between 2 and 10 times) sampled between 2006 and 2018 and are mostly located in the southern part of the Province of Alberta (Figure 1). The depth of the wells varies from $30 \mathrm{~m}$ to $213 \mathrm{~m}$ with an average of $79 \mathrm{~m}$ below ground surface (bgs) accessing groundwater from different shallow aquifers. The wells have typically stainless steel casing with diameters varying from $114 \mathrm{~mm}$ to $219 \mathrm{~mm}$ and most have short $(<10 \mathrm{~m})$ stainless steel or PVC screens limited to the target aquifer formation.

Of the 21 wells, three are screened within surficial glacial deposits while 18 wells reach sedimentary bedrocks including the following formations of Paleogene or Cretaceous age: Paskapoo Fm. (n=9), Horseshoe Canyon Fm. (n=4), Belly River/Oldman Fm. (n=4) or Bearpaw Fm. $(n=1)$. The terrestrial fluvial Paskapoo Formation consists of sequences of thick tabular sandstones overlain by interbedded siltstone and mudstone (Lyster and Andriashek, 2012; Dawson et al., 1994; Hamblin, 2004). The terrestrial fluvial Upper and Lower Horseshoe Canyon Formation is mainly composed of sand and coal, whereas the marine Middle Horseshoe Canyon formation consists predominantly of shale with bentonite and little sandstone or coal (Dawson et al., 1994). The Belly River Group formation consists of fluvial sandstone and siltstone with minor mudstone and coal. All these formations comprise heavily used aquifers in the prairie region of Alberta (Grasby et al., 2008). The coal zones with CBM potential are included in the Horseshoe Canyon and the Belly River formations. Thin coal seams also occur throughout the Paskapoo Formation. The reported aquifer lithologies often vary considerably within each well and from one well to the other, from sandstone to siltstone with intermittent coal or shale beds lenses, preglacial sand, or surficial sandy and gravelly lacustrine or moraine deposits, giving rise to complex multi-aquifer systems. More information about these geological formations can be found in Meyboom (1960), Rosenthal et al. (1984), Hamblin (1998), Hamblin (2004), Dawson et al. (1994), Lyster and Andriashek (2012), Grasby et al. (2008), and Prior et al. (2013). 
Figure 1: Location of the 21 groundwater monitoring wells selected for this study (ID and symbols). The red symbols refer to wells with groundwater having elevated concentrations of methane and black and green symbols refer to wells yielding groundwater with low concentrations of methane.

\section{Sampling, Methods and Obtained Results}

Two highly trained teams of sampling specialists from Alberta Environment and Parks (AEP) have collected aqueous and gaseous groundwater samples from GOWN wells since 2006 and the sampling campaigns are still ongoing. Groundwater samples repeatedly obtained from 21 GOWN wells selected for this study were analyzed for aqueous and gaseous geochemical compositions and isotopic compositions of various compounds using analytical procedures that are described in the Supplementary Information section and in previous publications (Humez et al., 2016a; Humez et al., 2016b). A total of 88 samples were analyzed for major ion chemistry including concentrations of $\mathrm{Ca}, \mathrm{Mg}, \mathrm{Na}, \mathrm{K}, \mathrm{SO}_{4}, \mathrm{NO}_{3}, \mathrm{Cl}$, and dissolved inorganic carbon (DIC), and concentrations of dissolved gases including methane. In addition, the isotopic compositions of dissolved methane $\left(\delta^{13} \mathrm{C}_{\mathrm{CH} 4}, \delta^{2} \mathrm{H}_{\mathrm{CH} 4}\right)$, sulfate $\left(\delta^{34} \mathrm{~S}_{\mathrm{SO} 4}, \delta^{18} \mathrm{O}_{\mathrm{SO} 4}\right)$ and DIC $\left(\delta^{13} \mathrm{C}_{\mathrm{DIC}}\right)$ were determined. The analytical data obtained for these groundwater samples from the 21 wells constitute a comprehensive, long-term monitoring record of dissolved gas contents, aqueous compositions, and isotopic fingerprints.

The analytical results for major and minor ion concentrations and isotopic fingerprints for the GOWN groundwater samples utilized for this study are summarized in Tables SI-1 and SI-2. The major ion concentrations vary widely and the water-types comprise $\mathrm{Ca}-\mathrm{HCO}_{3}, \mathrm{Na}-\mathrm{HCO}_{3}$ and $\mathrm{Na}$ $\mathrm{Cl}$ facies. Average concentrations of calcium and sodium varied from 0.02 to $3 \mathrm{mmol} / \mathrm{kgw}$ (millimoles per kilogram water) and from 8 to $70 \mathrm{mmol} / \mathrm{kgw}$ respectively (Table SI-1), while average chloride concentrations ranged between 0.01 and $40 \mathrm{mmol} / \mathrm{kgw}$ (Table SI-1). Groundwater samples were found to be in thermodynamic equilibrium with calcite present as cement in most of the studied aquifers (Hamblin, 2004; Grasby et al, 2008) resulting in buffered $\mathrm{pH}$ values of 7.6 to 9.2 and in alkalinity concentrations of 5.1 to $20 \mathrm{mmol} / \mathrm{kgw}$ (Table SI-1). In this $\mathrm{pH}$ range, the main inorganic carbon species is bicarbonate $\left(\mathrm{HCO}_{3}{ }^{-}\right)$. Methane was found to be ubiquitous in the groundwater samples with concentrations varying from $2.910^{-4}$ to 2.4 $\mathrm{mmol} / \mathrm{kgw}$. The highest concentrations of methane $(>0.01 \mathrm{mmol} / \mathrm{kgw})$ were found in the $\mathrm{Na}-$ 
$\mathrm{HCO}_{3}$ and $\mathrm{Na}-\mathrm{Cl}$ water-types where the sulfate concentrations are $<1 \mathrm{mmol} / \mathrm{kgw}$ as previously reported by Humez et al. (2016a,b).

The $\delta^{18} \mathrm{O}$ and $\delta^{2} \mathrm{H}$ values for groundwater varied from -24.0 to $-8.9 \%$ and from -191 to $-94 \%$ $v s$. VSMOW respectively, indicating atmospheric recharge of groundwater (Humez et al., 2016b). Average $\delta^{34} \mathrm{~S}_{\mathrm{SO} 4}$ values of sulfate ranged between +37 and $-10 \%$ vs. V-CDT and average $\delta^{18} \mathrm{O}_{\mathrm{SO} 4}$ values varied between -7.0 and $+7.9 \%$ vs. VSMOW (Table SI-2). Groundwater samples with the highest sulfate concentrations were characterized by $\delta^{34} \mathrm{~S}_{\mathrm{SO} 4}$ and $\delta^{18} \mathrm{O}_{\text {SO4 }}$ values $<0 \%$ o indicating that sulfate is predominantly derived from pyrite oxidation (Grasby et al., 2010). $\delta^{34} \mathrm{~S}_{\mathrm{SO} 4}$ values $>0 \%$ for individual samples are associated with the lowest sulfate concentrations suggesting that bacterial sulfate reduction may have occurred. Despite a narrow range in DIC concentrations, some $\delta^{13} \mathrm{C}_{\text {DIC }}$ values were as high as $+13.8 \%$ vs. V-PDB and ${ }^{13} \mathrm{C}$-enriched DIC was observed in samples with the highest methane concentrations $(>1.2 \mathrm{mmol} / \mathrm{kgw})$. The $\delta^{13} \mathrm{C}_{\mathrm{CH} 4}$ values varied from -84 to $-26 \%$ vs. V-PDB, the highest $\delta^{13} \mathrm{C}_{\mathrm{CH} 4}$ values being associated with the lowest methane concentrations $\left(2.910^{-4} \mathrm{mmol} / \mathrm{kgw}\right)$ suggesting methane oxidation.

4.

\section{Model development}

\subsection{Model framework}

The geochemical and isotopic evolution of the different species of interest was investigated using the geochemical modeling code PHREEQC (Parkhurst and Appelo, 1999) combined with the Thermoddem database (Blanc et al, 2007). The starting point of the modeling approach is the identification of the geochemical processes that can affect methane concentrations and isotopic compositions (see Supplementary Information). A key process is methane oxidation, which can occur when methane migrates into aquifer sections with more oxidizing conditions (half-reaction Eq. 1):

$\mathrm{CH}_{4}+3 \mathrm{H}_{2} \mathrm{O}=\mathrm{HCO}_{3}^{-}+9 \mathrm{H}^{+}+8 \mathrm{e}^{-}$

This oxidation reaction can proceed with several electron acceptors present in the groundwater samples. Measured dissolved oxygen concentrations in the Alberta groundwater samples (Tables SI-1 and SI-2) are consistently $<1.0 \mathrm{mg} / \mathrm{L}$, indicating anoxic or post-oxic conditions (Berner, 1981) while iron and manganese are present as reduced iron Fe(II) and manganese $\mathrm{Mn}$ (II) and 
have generally low concentrations (below $0.01 \mathrm{mmol} / \mathrm{kgw}$ ). Nitrogen is present almost exclusively as ammonium $\left(\mathrm{NH}_{4}{ }^{+}\right)$at concentrations of around $0.01 \mathrm{mmol} / \mathrm{kgw}$ while nitrate is negligible $(<0.005 \mathrm{mmol} / \mathrm{kgw}$, Table SI-1). As a result, the main electron acceptor in the groundwater samples is sulfate with concentrations as high as $10 \mathrm{mmol} / \mathrm{kgw}$. Therefore, methane oxidation in the shallow aquifers in Alberta proceeds almost exclusively coupled with bacterial sulfate reduction (Humez et al., 2016b); Eq. 2 combined with Eq. 1 gives the reaction Eq. 3:

$\mathrm{SO}_{4}{ }^{2-}+10 \mathrm{H}^{+}+8 \mathrm{e}^{-}=\mathrm{H}_{2} \mathrm{~S}+4 \mathrm{H}_{2} \mathrm{O}(2)$

$\mathrm{CH}_{4}+\mathrm{SO}_{4}{ }^{2-}+\mathrm{H}^{+}=\mathrm{HCO}_{3}^{-}+\mathrm{H}_{2} \mathrm{~S}+\mathrm{H}_{2} \mathrm{O}(3)$

Both processes are bacterially mediated and referred to as Anaerobic Oxidation of Methane (AOM) and Bacterial Sulfate Reduction (BSR). In this study, methanic conditions describe redox conditions where all electron acceptors have been consumed leading to the inhibition or considerable slowdown of AOM. Under these redox conditions, methane is stable and methane concentrations can build up. Additionally, lacking competition from sulfate reducers, methanogens can thrive and in-situ production of methane by microbial methanogenesis may become energetically favourable. Microbial methanogenesis proceeds via acetate fermentation or $\mathrm{CO}_{2}$ reduction. These pathways are characterised by distinct carbon and hydrogen isotope fractionation and can be identified using cross-plots of $\delta^{13} \mathrm{C}_{\mathrm{CH} 4}$ and $\delta^{2} \mathrm{H}_{\mathrm{CH} 4}$ or $\delta^{13} \mathrm{C}_{\mathrm{CO} 2}$ and $\delta^{13} \mathrm{C}_{\mathrm{CH} 4}$ values. According to the traditional plot of Whiticar et al. (1986) in Figure 2a, methane in the groundwater samples of this study was predominantly formed via the $\mathrm{CO}_{2}$ reduction pathway, confirmed by the more recent plots from Milkov and Etiope (2018) (Figures 2b and 2c). Therefore, methanogenesis will be modeled exclusively using the $\mathrm{CO}_{2}$ reduction pathway. It is interesting to note that the methane-poor groundwater samples (black label) are located outside of the fields of microbial methane production, suggesting that AOM may have occurred.

Figure 2: a) Plot of $\delta^{2} \mathrm{H}\left(\mathrm{CH}_{4}\right)$ vs. $\delta^{2} \mathrm{H}\left(\mathrm{H}_{2} \mathrm{O}\right)$ values and methanogenesis pathways boundaries from Whiticar (1986); b) $\delta^{13} \mathrm{C}\left(\mathrm{CH}_{4}\right)$ vs. $\delta^{2} \mathrm{H}\left(\mathrm{CH}_{4}\right)$ diagram from Milkov and Etiope (2018); c) $\delta^{13} \mathrm{C}\left(\mathrm{CO}_{2}\right)$ vs. $\delta^{13} \mathrm{C}\left(\mathrm{CH}_{4}\right)$ diagram from Milkov and Etiope (2018) with isotopic compositions of methane, $\mathrm{CO}_{2}$ and $\mathrm{H}_{2} \mathrm{O}$ from this study added.

\subsection{Isotope module setup}


Depending on the geochemical facies, the investigated groundwater samples can be separated in two zones named Zone 1 and Zone 2. The conceptual approach for distinguishing the two zones is summarized in Figure 3.

Figure 3: Conceptual description of initial hypotheses and geochemical and isotopic calculations in zones $1,2 \mathrm{a}$ and $2 \mathrm{~b}$ as developed in PHREEQC for this study.

5.2.1 Zone 1: post-oxic/sulfate-rich $(>1 \mathrm{mmol} / \mathrm{kgw})$ and methane-poor $(<0.01$ $\mathrm{mmol} / \mathrm{kgw}$ ) groundwater

Zone 1 is defined by a $\mathrm{SO}_{4}$-rich, $\mathrm{O}_{2}$-and $\mathrm{NO}_{3}$-depleted groundwater composition, typical of postoxic groundwater where most electron acceptors have already been reduced with the exception of sulfate. This zone comprises groundwater from 10 water wells (\#114, 126, 144, 148, 229, 234, 373, 381, 398, 481; black labels). These groundwater samples have low salinity (TDS <1000 $\mathrm{mg} / \mathrm{L}$; Table SI-1) and are characterized by $\mathrm{Ca}-\mathrm{HCO}_{3}$ or $\mathrm{Na}-\left(\mathrm{HCO}_{3}\right)-\mathrm{SO}_{4}$ water-types. Unpublished tritium and C-14 data suggest that these waters have residence times predominantly of only a few decades. They are also characterized by interactions with carbonate minerals (based on geochemical speciation and minerals saturation indexes calculated with PHREEQC), and are affected by pyrite oxidation as indicated by the isotopic composition of $\mathrm{SO}_{4}$ (high sulfate concentrations associated with both $\delta^{34} \mathrm{~S}_{\mathrm{SO} 4}$ and $\delta^{18} \mathrm{O}_{\mathrm{SO} 4}<0 \%$ see Tables SI-1 and SI-2). Pyrite is typical for glacial tills in Alberta, and its oxidation is responsible for the generally sulfate-rich groundwaters in parts of the province (Huff et al., 2012). In groundwater from the 10 water wells of zone 1 , methane concentrations were generally $<0.01 \mathrm{mmo} / \mathrm{kgw}$ indicating conditions that do not favor methane to accumulate due to methane oxidation. Methane in such sulfate-rich groundwater samples is metastable, as both compounds, if present at non-negligible concentrations, are thermodynamically incompatible with each other $\left(\Delta_{\mathrm{r}} \mathrm{G}^{0}=-109.4 \mathrm{~kJ} / \mathrm{mol}\right.$ for equation (3); Blanc et al. 2007). In addition, sulfate can inhibit methanogens from using the competitive substrates (Vinson et al., 2017) and thus the presence of sulfate in solution prevents methanogenic processes. The occurrence of low concentrations of methane in waters belonging to zone 1 therefore suggests an ongoing migration of methane either from methanogenic/methanic zones or from a deeper zone of thermogenic methane production. Once the methane reaches the sulfate-rich groundwater, anaerobic oxidation of methane (AOM) can occur coupled with bacterial sulfate reduction (BSR). 
Because of the comparativey low residence time of these waters, the quantity of available sulfate for AOM gets constantly replenished by lateral groundwater flows, while products of the AOM/BSR coupling such as DIC and sulfides are flushed from the methane intrusion point (= open system). If the recharge sulfate flux is larger than the intruding methane flux, the methane is oxidized and the zone remains sulfate-rich. In contrast, if the recharge sulfate flux is smaller than the intruding methane flux, the zone becomes more and more reducing with decreasing sulfate concentrations and potentially shifting to methanic or methanogenic conditions (zone 2, see section 4.2.2).

The mass balance for sulfate content at time $t+d t$ in an element volume of zone 1 can be expressed as:

$\mathrm{n}_{\mathrm{SO} 4}(\mathrm{t}+\mathrm{dt})=\mathrm{n}_{\mathrm{SO} 4}(\mathrm{t})+\mathrm{Q} \times\left\{\mathrm{SO}_{4}\right\}_{\mathrm{in}} \times \mathrm{dt}-\mathrm{Q} \times\left\{\mathrm{SO}_{4}\right\}(\mathrm{t}) \times \mathrm{dt}-\mathrm{r}_{\mathrm{CH} 4} \times \mathrm{dt}(4)$

with $n_{\mathrm{SO} 4}$ the amount of $\mathrm{SO}_{4}$ in the system [mol], $Q\left[\mathrm{~m}^{3} / \mathrm{s}\right]$ the constant water flow through the considered element volume $\mathrm{V}\left[\mathrm{m}^{3}\right]$. Multiplied by $\mathrm{SO}_{4}$ concentrations, it corresponds to the $\mathrm{SO}_{4}$ renewal/inflow flux and flushed $\mathrm{SO}_{4} /$ outflow flux. $\left\{\mathrm{SO}_{4}\right\}_{\text {in }}$ is the concentration in the inflow [mol. $\left.\mathrm{m}^{-3}\right]$ and $r_{\mathrm{CH} 4}\left[\mathrm{mol.s}{ }^{-1}\right]$ the reaction rate of BSR coupled with AOM, considered to be constant. If the system is considered to be in steady state conditions (i.e. $t \rightarrow \infty$ ), Eq. (4) can then be reduced to:

$\left\{\mathrm{SO}_{4}\right\}(t)=\left\{\mathrm{SO}_{4}\right\}_{\text {in }}-\frac{r_{\mathrm{CH}}}{Q}(5)$

The concentration of sulfate in the system during the steady-state is the difference between the constant renewal/recharge of sulfate and the constant methane input. If we define $\left\{\mathrm{SO}_{4}\right\}_{\text {in }}=\frac{n_{0}}{V}$ and $\frac{r_{C H 4}}{Q}=\frac{n C H 4}{V}$, this results in Equation 6:

$\left\{\mathrm{SO}_{4}\right\}(t)=\frac{n_{0}}{V}-\frac{n_{C H 4}}{V}(6)$

with $\mathrm{n}_{0}$ the initial quantity of sulfate in the considered element volume and $\mathrm{n}_{\mathrm{CH} 4}$ the total amount of methane added to the volume between $\mathrm{t}=0$ and $\mathrm{t}$. Equation (6) links the open system behavior to a hypothetical batch system (closed system) where the hypothetical initial quantities of sulfate 
and methane $\left(\mathrm{n}_{0}\right.$ and $\left.\mathrm{n}_{\mathrm{CH} 4}\right)$ can be derived from the actual fluxes of the open system $\left(\left\{\mathrm{SO}_{4}\right\}_{\text {in }}\right.$ and $\left.\frac{r_{C H 4}}{Q}\right)$. This simplifies the modeling considerably as PHREEQC is designed to handle batch systems. In the following, the open system of zone 1 will be modeled as a closed system through the transformation defined in Equation 6.

Since the actual system is an open system, products of AOM and BSR are being flushed away from the considered volume by groundwater movements and the reactants are replenished. This process is similar to a Rayleigh distillation as shown in Equation 7 for methane and Equation 8 for sulfate:

$\delta^{13} \mathrm{C}_{\mathrm{CH} 4}=\delta^{13} \mathrm{C}_{\mathrm{CH} 4-\text { fugitive }}+\varepsilon_{\text {DIC-CH4 }} \ln \mathrm{f}(7)$

$\delta^{34} \mathrm{~S}_{\mathrm{SO} 4}=\delta^{34} \mathrm{~S}_{\mathrm{SO} 4-\text { initial }}+\varepsilon_{\mathrm{H} 2 \mathrm{~S}-\mathrm{SO} 4} \ln \mathrm{f}(8)$

with $\mathrm{f}=\left[\mathrm{CH}_{4}\right] /\left[\mathrm{CH}_{4}\right]_{0}\left(\mathrm{resp} .=\left[\mathrm{SO}_{4}\right] /\left[\mathrm{SO}_{4}\right]_{0}\right)$, the fraction of remaining methane or sulfate after oxidation with respect to the initial fugitive methane and sulfate concentrations in the zone. Carbon and sulfur isotope enrichment factors between DIC and methane and between $\mathrm{H}_{2} \mathrm{~S}$ and sulfate are $\varepsilon_{\mathrm{DIC}-\mathrm{CH} 4}$ and $\varepsilon_{\mathrm{H} 2 \mathrm{~S}-\mathrm{SO} 4} \cdot \delta^{13} \mathrm{C}_{\mathrm{CH} 4 \text {-fugitive }}$ represents the carbon isotope ratio of the fugitive methane source prior to oxidation and $\delta^{34} \mathrm{~S}_{\mathrm{SO} 4 \text {-initial }}$ is the initial sulfur isotope ratio of dissolved sulfate prior to methane intrusion.

However, the ${ }^{34} \mathrm{~S} /{ }^{32} \mathrm{~S}$ ratios of sulfate and ${ }^{13} \mathrm{C} /{ }^{12} \mathrm{C}$ ratios of methane are modified by isotope fractionation during bacterial sulfate reduction and methane oxidation, but also by the amount of fresh sulfate and methane being replenished by recharge waters and methane intrusion. This isotopic "dilution" is considered in this study by introducing an apparent enrichment factor $\varepsilon^{\prime}{ }_{a-b}=\varepsilon_{a-b}(1-\beta)$ which includes the intrinsic enrichment factor $\varepsilon_{a-b}$ from the literature, and $\beta$ a recharge factor. The limiting values are $\beta=1$ (the net stream input is equal to the quantity of consumed sulfate and methane), and hence the sulfate and methane concentrations and stable isotope compositions remain constant, and $\beta=0$ (no flux, classical Rayleigh equation).

Finally, in such an open system the inorganic carbon pool is constantly renewed by the groundwater flow and to a lesser extent by calcite dissolution. Therefore, for zone 1 it is assumed that the isotopic composition of the DIC is imposed by the isotopic equilibrium between atmospheric $\mathrm{CO}_{2}$ and calcite in an open system and is thus not affected by methane oxidation. 


\subsubsection{Zone 2: sulfate-poor ( $<1 \mathrm{mmol} / \mathrm{kgw})$ groundwater}

About half of the groundwater samples from the monitoring wells are $\mathrm{SO}_{4}$-poor $(<1 \mathrm{mmol} / \mathrm{kgw})$ with either high concentrations of methane (> $0.01 \mathrm{mmol} / \mathrm{kgw}-9$ wells \# 214, 310, 311, 333, $456,438,439,982,991)$ or low concentrations of methane $(<0.01 \mathrm{mmol} / \mathrm{kgw}-2$ wells \#140, 984). These conditions can be reached through two different pathways: (1) a large influx of methane into a sulfate rich groundwater zone followed by extensive BSR resulting in low sulfate concentrations (ultimate evolution of zone 1), or (2) through a groundwater which was never in contact with large amounts of pyrite and in which high sulfate concentrations never built up. Low sulfate concentrations are compatible with the presence of high methane concentrations. The difference between zone $2 \mathrm{a}$ and $2 \mathrm{~b}$ is the origin of the methane. Zone $2 \mathrm{a}$ is characterized by fugitive methane migrating into the aquifer from below reaching favorable redox condition for the methane to remain stable. Zone $2 \mathrm{~b}$ is characterized by in situ methane production within the aquifer.

Since the oxidation potential decreases along the groundwater flowpath, groundwater that accumulates methane may have a longer residence time (Bates et al., 2011). In such conditions, the groundwater flow is considered negligible, meaning that no recharge and flushing of the dissolved species (except for $\mathrm{H}_{2} \mathrm{~S}$ ) needs to be considered, contrary to zone 1 . This implies that sulfur isotope ratios of sulfate will evolve following Equation 8 with the intrinsic sulfur isotope enrichment factor varying between -15 to $-42 \%$ (Krouse, 1977; Krouse 1980; Aravena and Mayer, 2009) instead of the apparent isotope enrichment factor used in zone 1. Furthermore, the closed system implies that $\delta^{13} \mathrm{C}$ values of methane and DIC will not follow a Rayleigh distillation equation and therefore are best calculated with a mass balance equation.

Additionally, equilibrium with calcite will play a larger role than in zone 1 in the closed system of zone 2. Methane oxidation produces DIC, which triggers calcite precipitation. However, methanogenesis consumes $\mathrm{H}^{+}$as described in Eq. SI-6, which increases the $\mathrm{pH}$. Since the solubility of calcite increases with decreasing DIC and decreases with increasing $\mathrm{pH}$, methanogenesis has a non-trivial effect on calcite solubility and both dissolution and precipitation need to be considered in the modelling of zone $2 \mathrm{~b}$. Finally, since the carbon isotope ratio of the precipitated calcite and the remaining methane at a date $t$ will depend on the DIC at that same 
time $t$, the whole process needs to be divided into infinitesimal steps that calculate the chemical and isotopic compositions of the solution at each time step. In practice, the calculation proceeds in 100 steps.

Zone 2a: Methanic conditions

For zone 2a, the evolution of the $\delta^{13} \mathrm{C}$ value of DIC in solution is described by Equation (9):

$$
\delta^{13} C_{D I C}(i+1)=\frac{\delta^{13} C_{D I C}(i)\{D I C\}(i)+d n_{C H 4}\left(\delta^{13} C_{C H 4}(i+1)+\varepsilon_{D I C-C H 4}\right)-\mathrm{dn}_{\text {cal }} \varepsilon_{c a l-D I C}}{\{D I C\}(i+1)+\mathrm{dn}_{c a l}}(9)
$$

with $\{$ DIC $\}$ the molality of dissolved inorganic carbon and $\mathrm{dn}_{\mathrm{CH} 4}$ the quantity of methane oxidized between steps $\mathrm{i}$ and $\mathrm{i}+1, \mathrm{dn}_{\text {cal }}$ the quantity of DIC removed through calcite precipitation between $\mathrm{i}$ and $\mathrm{i}+1$, and $\varepsilon_{c a l-D I C}$ the carbon isotope enrichment factor for calcite precipitation.

For zone 2a, the isotope mass balance for carbon isotope ratios of methane depends on the proportion of methane that was oxidized and is calculated as follows:

$\delta^{13} C_{C H 4}(i+1)=\frac{\delta^{13} C_{C H}(i)\left\{\mathrm{CH}_{4}\right\}(i)-d n_{\mathrm{CH}} \varepsilon_{\mathrm{DIC}-\mathrm{CH} 4}}{\left\{\mathrm{CH}_{4}\right\}(i+1)+d n_{\mathrm{CH}}}(10)$

Zone 2b: Methanogenic conditions

In contrast to zone $2 \mathrm{a}$, methane is produced in-situ in zone $2 \mathrm{~b}$. Two reactions need to be considered: (1) methanogenesis via the $\mathrm{CO}_{2}$ reduction pathway consuming DIC and producing methane with a specific carbon isotope enrichment factor through a specific microorganism consortium, and (2) oxidation of the produced methane coupled with bacterial sulfate reduction decreasing sulfate concentrations while adding to the inorganic carbon pool mediated by another specific microorganism consortium. In addition, the groundwater in zone $2 \mathrm{~b}$ is considered to be in equilibrium with calcite. Figure 4 summarizes how $\mathrm{CH}_{4}, \mathrm{DIC}, \mathrm{SO}_{4}$ and calcite are interlinked and describes the conceptual scheme for zone $2 b$.

Figure 4: Interplay between methanogenesis via $\mathrm{CO}_{2}$ reduction and bacterial oxidation of produced methane coupled with bacterial sulfate reduction. 
Calculations of $\delta^{13} \mathrm{C}_{\text {DIC }}$ values in zone $2 \mathrm{~b}$ are performed in a similar fashion as described above for zone $2 \mathrm{a}$ while differentiating whether calcite is dissolving or precipitating. For calcite precipitation, the evolution for the $\delta^{13} \mathrm{C}$ value of DIC at a step $\mathrm{i}+1$ is expressed as follows:

$$
\begin{aligned}
& \delta^{13} C_{D I C}(i+1) \\
& =\frac{\delta^{13} C_{D I C}(i)\{D I C\}(i)+d n_{C H 4}\left(\delta^{13} C_{C H 4}(i+1)+\varepsilon_{D I C-C H 4}\right)-\mathrm{dn}_{\text {cal }} \varepsilon_{\text {cal-DIC }}-\mathrm{dn}_{\text {methano }} \varepsilon_{\text {methano }}}{\{D I C\}(i+1)+\mathrm{dn}_{\text {cal }}+\mathrm{dn}_{\text {methano }}}
\end{aligned}
$$

with $\{$ DIC $\}$ the molality of dissolved inorganic carbon, $\mathrm{dn}_{\mathrm{cal}}$ the quantity of DIC removed from the solution by calcite precipitation $(>0)$ between $i$ and $i+1$, and $n_{\text {methano }}$ the quantity of DIC removed by methanogenesis $(>0)$.

The $\delta^{13} \mathrm{C}$ values of marine carbonates vary between $0 \%$ and $+2 \%$ (Gautschi et al., 1991) and we used $\delta^{13} \mathrm{C}_{\text {calcite }}$ of $0 \%$ in this study. Since calcite dissolution is considered to be a nonfractionating process Equation (11) becomes:

$$
\delta^{13} C_{D I C}(i+1)=\frac{\delta^{13} C_{D I C}(i)\{D I C\}(i)+d n_{C H 4}\left(\delta^{13} C_{C H 4}(i+1)+\varepsilon_{D I C-C H 4}\right)+d n_{\text {methano }} \varepsilon_{\text {methano }}}{\{D I C\}(i+1)+d n_{\text {methano }}}
$$

\section{Application of the Model to Alberta Groundwater Data}

\subsection{Description of the modeling scenarios}

A series of scenarios with different initial conditions were selected for zones 1 and $2 \mathrm{a}, \mathrm{b}$ (Table 1). In all the scenarios, incremental quantities of methane (from $10^{-7}$ to $1 \mathrm{~mol} / \mathrm{kgw}$ ) were added to the batch system and the final geochemical and isotopic compositions of dissolved groundwater constituents were calculated with PHREEQC as described in the previous section. The variables considered were the isotopic composition of fugitive methane for zone 1 and $2 \mathrm{a}\left(\delta^{13} \mathrm{C}_{\mathrm{CH} 4 \text {, fugitive }}\right)$, the initial ${ }^{34} \mathrm{~S} /{ }^{32} \mathrm{~S}$ ratio of sulfate in groundwater $\left(\delta^{34} \mathrm{~S}_{\mathrm{SO} 4 \text {,initial }}\right.$ - indicative of pyrite oxidation $)$, the intrinsic $\left(\varepsilon_{\mathrm{H} 2 \mathrm{~S}-\mathrm{SO} 4}, \varepsilon_{\mathrm{DIC}-\mathrm{CH} 4}, \varepsilon_{\text {methanogenesis }}\right)$ or apparent $\left(\varepsilon^{\prime}{ }_{\text {DIC-CH4 }}, \varepsilon^{\prime}{ }_{\text {H2S-SO } 4}\right)$ carbon and sulfur isotope enrichment factors, the initial concentration of sulfate $\left(\mathrm{SO}_{4}\right.$ initial reservoir $)$ for zone 1 and the initial 
DIC concentration (DIC initial $)$ for zone 2 as well as the initial carbon isotope composition of DIC $\left(\delta^{13} \mathrm{C}_{\text {DIC }}\right)$.

Three different carbon isotope ratios for fugitive methane were chosen to represent a wide range of $\delta^{13} \mathrm{C}$ values indicative of microbial $(-80 \%,-110 \%)$ and late mature thermogenic $(-35 \%)$ methane origin. Three apparent carbon isotope enrichment factors $\varepsilon^{\prime}{ }_{\text {DIC-CH4 }}=-10 \%,-5 \%$ and $2 \%$ were also considered in order to take into account the recharge effect on DIC in zone 1. Carbon isotope enrichment factors for bacterial methane oxidation $\left(\varepsilon_{\text {DIC-CH4 }}\right)$ of $-15,-10$ and $-5 \%$ o were used for intrinsic enrichment factors in zone 2 (Whiticar, 1999). The apparent sulfur isotope enrichment factor $\left(\varepsilon^{\prime}{ }_{\mathrm{H} 2 \mathrm{~S}-\mathrm{SO} 4}\right)$ for BSR was $-5 \%$ in zone 1 , while the intrinsic $\varepsilon_{\mathrm{H} 2 \mathrm{~S} \text {-SO4 } 4}$ was chosen between -15 and $-42 \%$ in zone 2 to represent the full range of literature values (Krouse, 1977; Krouse 1980; Aravena and Mayer, 2009). Finally, in order to consider the effect of recharge on the sulfate balance, four initial sulfate concentrations were chosen at 0.2, 0.085, 0.008 and 0.002 $\mathrm{mol} / \mathrm{kgw}$.

The initial $\delta^{13} \mathrm{C}$ value of $\mathrm{CO}_{2}$ in zone 2 was either $-20 \%$ or $-30 \%$ corresponding to the typical range of carbon isotope ratios for $\mathrm{CO}_{2}$ in soils derived from $\mathrm{C}_{3}$ plants (Rightmire and Hanshaw, 1973). Three different initial DIC concentrations were considered at $0.02,0.01$ and $6.10^{-3}$ $\mathrm{mol} / \mathrm{kgw}$ and two different carbon isotope enrichment factors for methanogenesis $\left(\varepsilon_{\text {methanogenesis }}\right) \square$ of $-60 \%$ and $-95 \%$ (Whiticar and Faber, 1986).

Table 1: Parameters of the different scenarios used for simulating carbon and sulfur isotope evolution in Zone 1, 2a and $2 \mathrm{~b}$.

Zone 1: Fugitive methane in post-oxic/ $/ \mathrm{SO}_{4}$-rich groundwater

\begin{tabular}{|c|c|c|c|c|c|}
\hline Scenario & $\underbrace{\mathrm{SO}_{4} \text { initial }}_{\text {reservoir }}$ & $\delta^{13} \mathrm{C}_{\mathrm{CH} 4 \text {, fugitive }}$ & $\begin{array}{l}\varepsilon_{\text {DIC- }}^{\prime} \\
\mathrm{CH} 4^{\prime}\end{array}$ & $\delta^{34} \mathrm{~S}_{\mathrm{SO} 4 \text {,initial }}$ & $\varepsilon^{\prime}{ }_{\mathrm{H} 2 \mathrm{~S}-\mathrm{SO} 4}$ \\
\hline & $\mathrm{mol} / \mathrm{kgw}$ & $\%$ & $\%$ & $\%$ & $\%$ \\
\hline A1 & 0.2 & -80 & -5 & -25 & -5 \\
\hline B1 & 0.2 & -80 & -10 & -15 & -5 \\
\hline $\mathrm{C} 1$ & 0.2 & -80 & -2 & -5 & -5 \\
\hline D1 & 0.002 & -80 & -5 & -15 & -5 \\
\hline E1 & 0.2 & -35 & -5 & -15 & -5 \\
\hline $\mathrm{F} 1$ & 0.2 & -110 & -5 & -15 & -5 \\
\hline
\end{tabular}


$\begin{array}{llllll}\text { G1 } & 0.085 & -110 & -5 & -15 & -5 \\ \text { H1 } & 0.008 & -80 & -5 & -15 & -5\end{array}$

Zone 2a: Methanic conditions

\begin{tabular}{|c|c|c|c|c|c|c|}
\hline & $\mathrm{DIC}_{\text {initial }}$ & $\delta^{13} \mathrm{C}_{\mathrm{CH} 4 \text {, fugitive }}$ & $\varepsilon_{\text {DIC-CH4 }}$ & $\delta^{34} \mathrm{~S}_{\mathrm{SO} 4 \text {, initial }}$ & $\varepsilon_{\mathrm{H} 2 \mathrm{~S}-\mathrm{SO} 4}$ & $\delta^{13} \mathrm{C}_{\mathrm{CO} 2(\mathrm{~g})}$ \\
\hline & $\mathrm{mol} / \mathrm{kgw}$ & $\%$ & $\%$ & $\%$ & $\%$ & $\%$ \\
\hline $\mathrm{A} 2$ & 0.01 & -80 & -5 & -25 & $-15 \&-42$ & -20 \\
\hline $\mathrm{B} 2$ & $6.10^{-3}$ & -80 & -10 & -15 & $-15 \&-42$ & -20 \\
\hline $\mathrm{C} 2$ & 0.02 & -80 & -15 & -5 & $-15 \&-42$ & -20 \\
\hline D2 & 0.02 & -80 & -5 & -15 & -42 & -20 \\
\hline $\mathrm{E} 2$ & 0.02 & -110 & -5 & -15 & $-15 \&-42$ & -30 \\
\hline
\end{tabular}

Zone 2b: Methanogenic conditions via $\mathrm{CO}_{2}$ reduction pathway

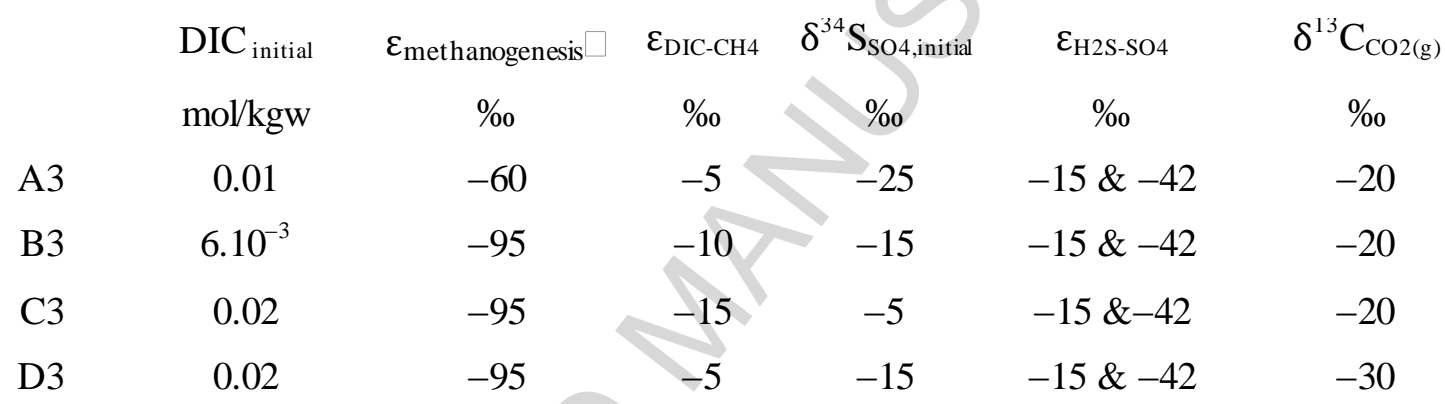

By convention: all fractionation factors $\varepsilon$ are defined as $\varepsilon_{b-a}=\delta_{b}-\delta_{a}$ where $\delta$ is the relative deviation of the isotopic ratios of a the reactant and $b$ the product of reaction from an international standard.

\subsection{Geochemical evolution of the $\mathrm{CH}_{4}$-calcite- $\mathrm{SO}_{4}$ system}

The intrusion of methane into the initially $\mathrm{SO}_{4}$-rich groundwaters of zone 1 depletes the systems in sulfate through the combined action of AOM and BSR. Figure 5 shows the modeling results as solid lines (scenarios A1, G1 and H1) and dashed lines (D1). An anti-correlation between sulfate and methane concentrations is observed (i.e. the higher the methane content, the lower the sulfate concentration) following a 1:1 ratio since one mole of sulfate reacts with one mole of methane as described by Equation 3. The grey line represents the boundaries of zone 1 (Figure 5).

Figure 5: Evolution of sulfate versus dissolved methane concentrations in simulations and in groundwater from the 21 monitoring water wells. 
In zone $2 \mathrm{a}$, the fugitive methane is penetrating a zone where redox conditions can allow its presence and persistence. However, a small proportion of the fugitive methane will still be oxidized coupled with bacterial reduction of the remaining residual sulfate. This results in a slight increase of the DIC content (blue lines in Figure 6 corresponding to the methanic zone 2a). The methane oxidation process is limited by the low availability of sulfate allowing large concentrations of methane (up to saturation) to build up.

For zone $2 b$, two competing processes are at play: (1) the main process of methanogenesis simulated by $\mathrm{CO}_{2}$ reduction and (2) the limited reduction of the remaining sulfate present in low concentrations $<1 \mathrm{mmol} / \mathrm{kgw}$ coupled with the oxidation of the produced methane. Both anaerobic methane oxidation coupled with BSR and methanogenesis impact the DIC pool in the aquifer. However, considering the low to negligible sulfate concentrations, the effect of methanogenesis on the DIC pool will be dominant. Orange lines corresponding to zone $2 \mathrm{~b}$ scenarios in Figure 6 show the impact of methanogenesis via DIC reduction on the carbonate equilibrium of the batch simulations. It is interesting to see that calcite dissolution does not compensate the DIC removal from solution by methanogenesis, because of the concomitant $\mathrm{pH}$ increase, which decreases calcite solubility.

Figure 6: Relationship between DIC and dissolved methane concentrations for zones 2a (blue lines) and $2 \mathrm{~b}$ (oranges lines) for groundwater from the 21 monitoring water wells. A2, A3, B2, B3, C2 and C2 refer to scenarios explained in Table 1.

The different scenarios are adequately characterizing the data for GOWN groundwater samples with the exception of the samples shown in green where both sulfate and methane concentrations are low and plot below scenarios A, B and C (Figure 6). In contrast, groundwater from well \#214 had an unusually high DIC content as shown on Figure 6, plotting on the right of scenarios $\mathrm{C} 2 / \mathrm{C} 3$. This may be the result of a different geochemical reaction decreasing $\mathrm{pH}$ and allowing for more calcite dissolution. 


\subsection{Isotopic evolution of the $\mathrm{CH}_{4}$-calcite-SO 4 system}

\subsubsection{C isotope evolution of methane}

Both methane oxidation and methanogenesis processes have a strong impact on the carbon (and hydrogen) isotope ratio of methane. For zone 1 and $2 \mathrm{a}$, the fugitive methane arrives in the aquifer from below with a constant isotopic composition and is then oxidized. Since methane oxidation fractionates carbon isotopes favoring the lighter ${ }^{12} \mathrm{C}$ in the produced $\mathrm{CO}_{2}$, the remaining methane becomes progressively enriched in ${ }^{13} \mathrm{C}$ (Barker and Fritz, 1981). Figure 7 represents the evolution of $\delta^{13} \mathrm{C}$ of methane during AOM coupled with BSR. Scenarios A1, F1 and G1 represent the intrusion of microbial methane with $\delta^{13} \mathrm{C}$ values of -80 and $-110 \%$ respectively, while E1 represents the intrusion of thermogenic methane with a $\delta^{13} \mathrm{C}$ value of $-35 \%$.

As represented in Figure 7, methane in zone 1 (black lines) is characterized by a significant ${ }^{13} \mathrm{C}$ enrichment of up to $60 \%$ compared to the carbon isotope ratio of the original methane during AOM coupled with BSR. When following the black lines of Figure 7 towards lower sulfate concentrations, the remaining methane concentration increases (Figure 5), and thus the $\delta^{13} \mathrm{C}_{\mathrm{CH} 4}$ values of the remaining methane approach asymptotically the initial $\delta^{13} \mathrm{C}_{\mathrm{CH} 4}$ value of the fugitive methane, corresponding to large amounts of methane and small amounts of sulfate. Even if black lines are theoretically only valid for zone 1 , those scenarios have been prolonged for sulfate concentrations below $1 \mathrm{mmol} / \mathrm{kgw}$, to show the effect of complete BSR coupled with oxidation of methane that intruded into an initially sulfate rich aquifer (Figure 7). The different scenarios are adequately characterizing the data for GOWN groundwater samples. Figure 8 displays the effect of different $\mathrm{C}$ isotope enrichment factors for methane oxidation for zone 1 with scenarios $\mathrm{A} 1, \mathrm{~B} 1$ and $\mathrm{C} 1$ representing respectively apparent enrichments factors of $-2 \%,-5 \%$, and $-10 \%$, respectively. The apparent enrichment factor affects the steepness of the Rayleigh distillation curve, with a steeper curve for higher $\varepsilon \square$ values; values in the range of -5 and $-2 \%$ seem more realistic for the groundwater samples.

Figure 7: Evolution of $\delta^{13} \mathrm{C}$ values of methane versus sulfate concentrations during the simulations of zones 1 (black label), 2a (blue lines) and $2 \mathrm{~b}$ (orange lines). Scenarios names from Table 1 are indicated on the Figure. 
Processes that impact the $\delta^{13} \mathrm{C}$ values of methane are similar in zone 2a compared to those in zone 1 (blue lines, Figure 7). The initial $\delta^{13} \mathrm{C}_{\mathrm{CH} 4}$ value from fugitive methane increases at first as a consequence of methane oxidation coupled with BSR and then decreases again toward the isotopic composition of the fugitive methane with increasing methane concentration in the system (Figure 7). The three scenarios A2, B2 and $\mathrm{C} 2$ differ only in the $\mathrm{C}$ isotope enrichment factor for bacterial methane oxidation $\left(\varepsilon_{\mathrm{DIC}-\mathrm{CH} 4}\right)$ equal to $-5 \%$, $-10 \%$, and $-15 \%$, respectively. Finally, in zone $2 \mathrm{~b}$, the model considers that methanogenesis is consuming DIC to produce methane while the reduction of low to negligible remaining sulfate oxidizes only a small quantity of the produced methane (see Figure 4 for the conceptual interplay). Scenarios describing methanogenesis are represented with orange lines in Figure 7 and show a very sharp increase of $\delta^{13} \mathrm{C}_{\mathrm{CH} 4}$ values up to $>+25 \%$ or sulfate concentrations around $5.10^{-6} \mathrm{~mol} / \mathrm{kgw}$ as the remaining DIC substrate is getting enriched in ${ }^{13} \mathrm{C}$.

Figure 8: Effect of apparent carbon isotope enrichment factors $\varepsilon^{\prime}{ }_{\text {DIC-CH4 }}$ during the methane oxidation process on fugitive methane $\delta^{13} \mathrm{C}_{\mathrm{CH} 4}$ values intruding zone 1.

\subsection{2 $\mathrm{S}$ isotope evolution of sulfate}

As bacterial sulfate reduction in the model is calculated as a Rayleigh distillation process in all 3 zones, scenarios plot as straight lines with slope $\varepsilon$ (or $\left.\varepsilon^{\prime}\right)$ in the $\delta^{34} \mathrm{~S}$ versus $\log \left(\mathrm{SO}_{4}\right)$ concentration plot in Figure 9. As described in the model set-up, zone 1 is characterized by a lower apparent sulfur isotope enrichment factor for BSR due to the influence of the recharge of fresh sulfate-rich groundwater. As mentioned in section 5.2, sulfate renewal is not considered for zones $2 \mathrm{a}$ and $2 \mathrm{~b}$ and the $\mathrm{S}$ isotope enrichment factor for BSR becomes equal to the intrinsic enrichment factor from the literature. Two different slopes for zone 2 are represented in Figure 9 with $\varepsilon_{\mathrm{SO}-\mathrm{HS}}=-15 \%$ and $-42 \%$ showing the full extent of the literature range (Aravena and Mayer, 2009). Scenarios are differentiated by their initial sulfate content and initial $\delta^{34} S$ values. The influence of these two parameters can be seen in Figure 9: increasing the initial sulfate concentration moves the line up while decreasing the initial $\delta^{34} \mathrm{~S}$ value moves the line down. The different scenarios are adequately characterizing the data for GOWN groundwater samples with the exceptions of the groundwater samples \#310/311, \#214, \#991 and \#333 (see discussion in section 5.4). 
Figure 9: a) Evolution of $\delta^{34} \mathrm{~S}$ values of sulfate versus sulfate concentration $\left(\log \left(\mathrm{SO}_{4}\right)\right)$ in zones 1 , $2 \mathrm{a}$ and $2 \mathrm{~b}$. The black lines represent the scenarios of zone 1 and the red lines the undifferentiated zones $2 \mathrm{a}$ and $2 \mathrm{~b}$; b) Conceptual scheme of the impact of the presence/absence of $\mathrm{SO}_{4}$ renewal and dilution processes on sulfur isotope enrichment factors $\varepsilon_{\mathrm{H} 2 \mathrm{~S}-\mathrm{SO} 4}$ and $\delta^{34} \mathrm{~S}$.

\subsubsection{C isotope evolution of DIC}

Figure 10 depicts the evolution of $\delta^{13} \mathrm{C}$ values of DIC with sulfate concentrations. For zone 1 , the DIC pool is considered as renewed and thus presents a constant $\delta^{13} \mathrm{C}$ value depending on the relative influences of $\mathrm{CO}_{2}$ derived from organic matter decomposition and calcite dissolution. Two characteristic $\delta^{13} \mathrm{C}$ values for DIC are represented at -13\%o and-20\%o (Figure 10) (Rightmire and Hanshaw, 1973; Kloppmann et al., 1998).

In zones $2 \mathrm{a}$ and $2 \mathrm{~b}$, the evolution of $\delta^{13} \mathrm{C}$ values of DIC is very different depending on the type of processes involved (Figure 10, orange and blue lines). In the methanic zone $2 \mathrm{a}$, the $\delta^{13} \mathrm{C}$ value of DIC decreases slowly, following the small increase of DIC concentration (see Figure 6) as a result of methane oxidation coupled with BSR. In contrast, the $\delta^{13} \mathrm{C}$ value of DIC increases markedly during methanogenesis by up to $+30 \%$ o for low sulfate concentrations $<10^{-5} \mathrm{~mol} / \mathrm{kgw}$ (Zone 2b, Figure 10, orange lines). As the pool of DIC becomes smaller due to the $\mathrm{CO}_{2}$ consumption by methanogenesis, the remaining DIC becomes strongly enriched in ${ }^{13} \mathrm{C}$ resulting in a marked $\delta^{13} \mathrm{C}_{\mathrm{DIC}}$ increase during methanogenesis. The $\mathrm{C}$ isotope ratio of DIC can thus be a very clear marker of such process occurring in the groundwater.

Figure 10: Evolution of the $\delta^{13} \mathrm{C}_{\text {DIC }}$ values versus sulfate concentrations [log] in zones 1 (black lines), 2a (blue lines) and $2 \mathrm{~b}$ (orange lines).

\subsection{Classification of groundwater from the monitoring wells}

The geochemical and isotopic model results allow the attribution of groundwaters from the 21 wells to five categories and also enables the assessment of the initial isotopic composition of the 
methane they contain and of the processes which led to the measured groundwater composition (Table 2).

Table 2: Definition of the different categories based on the modeling approach.

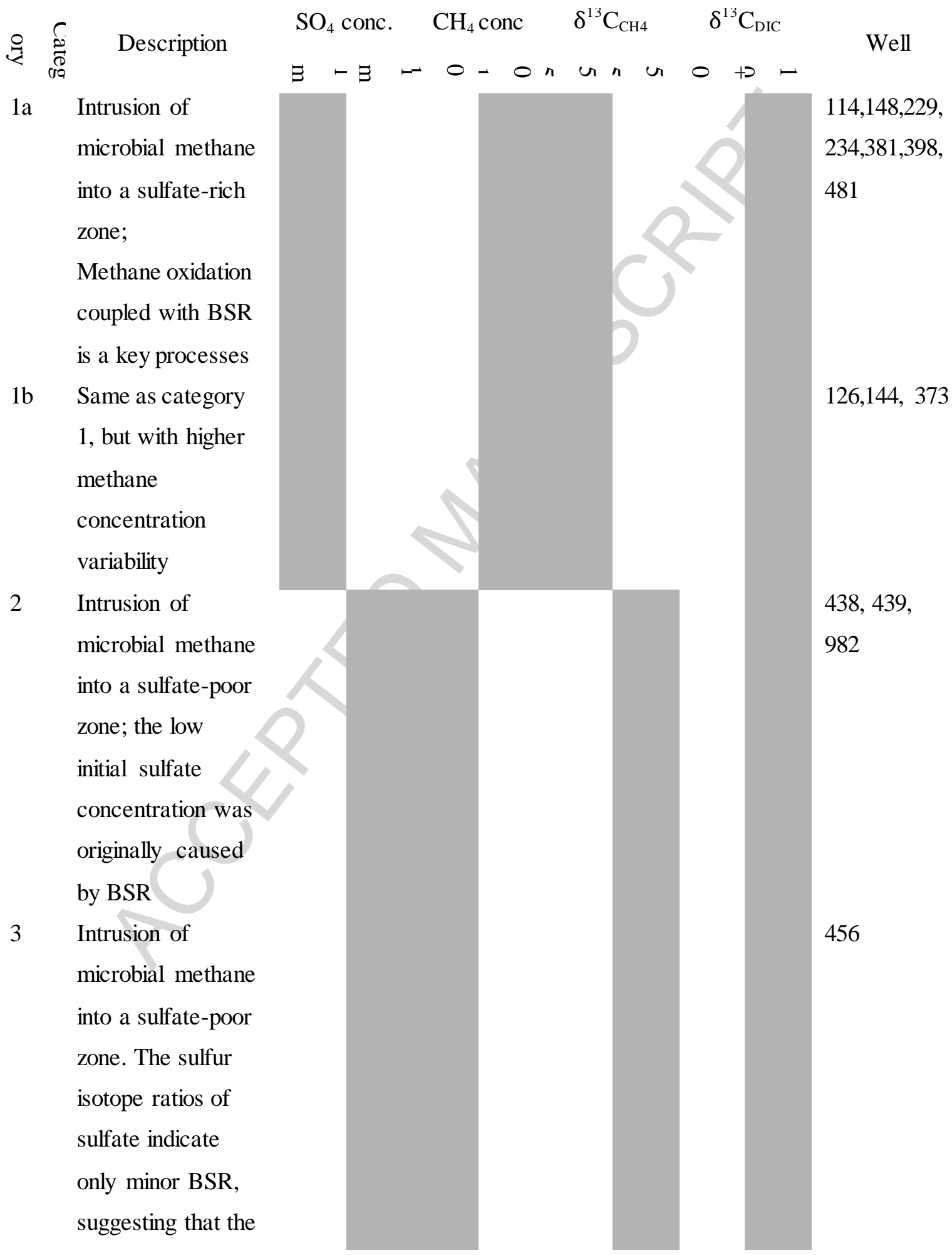




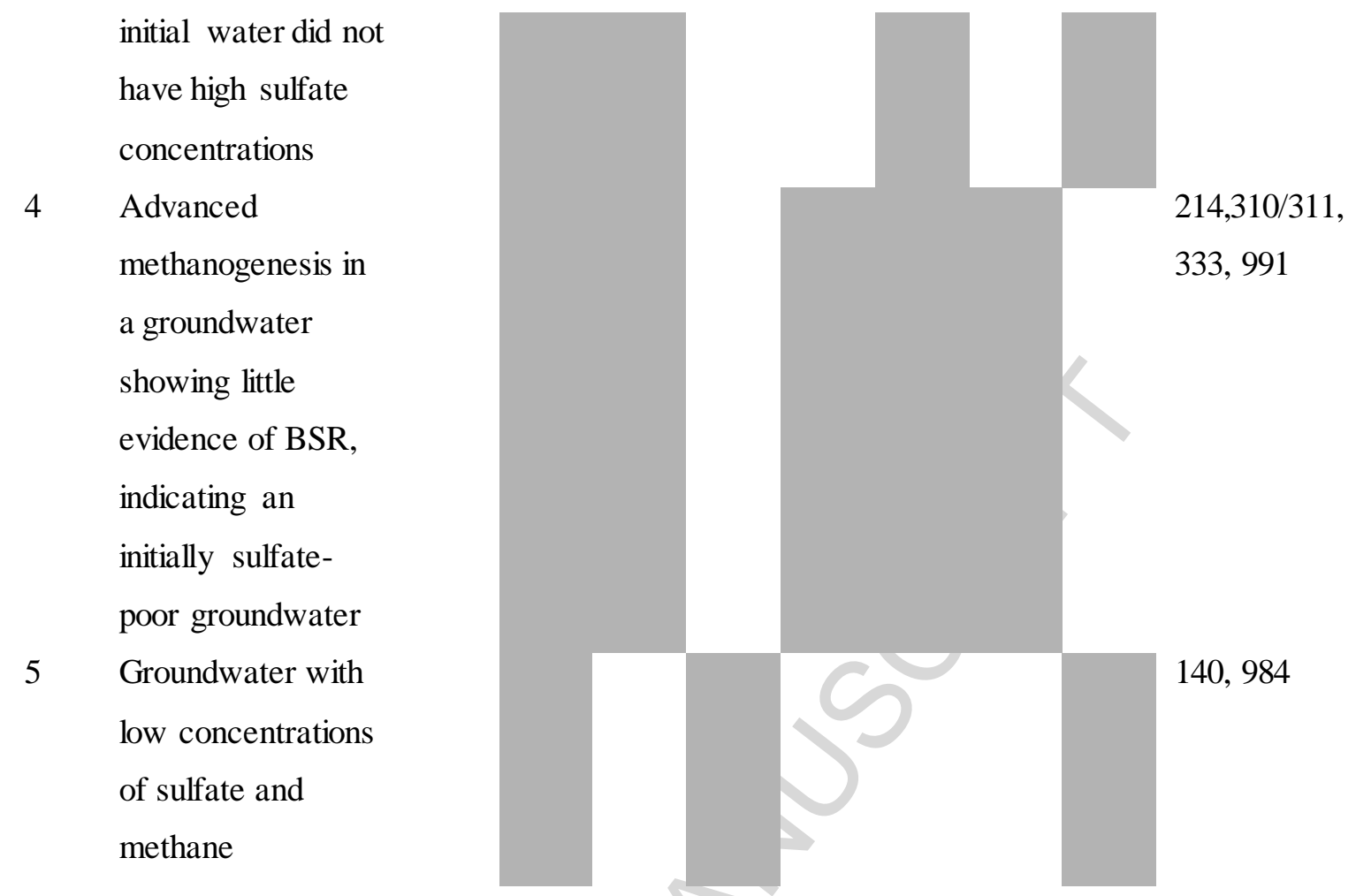

The first category includes groundwater from wells \#114, \#148, \#229, \#234, \#381, \#398, \#481, \#126, \#144 and \#373. The geochemical and isotopic model shows that these groundwater samples have been impacted by the migration of microbial methane with $\delta^{13} \mathrm{C}_{\mathrm{CH} 4}$ values varying from $110 \%$ to $-80 \%$ into a $\mathrm{SO}_{4}$-rich groundwater (zone 1). The subsequent oxidation of methane increased the initial $\delta^{13} \mathrm{C}$ values of methane by 50 to $70 \%$ o to $\delta^{13} \mathrm{C}$ values of -55 to $-25 \%$ (Figure 7) resulting in a misleading pseudo-thermogenic $\mathrm{C}$ isotope signature of the remaining methane. Methane oxidation coupled with BSR is also evidenced by the $\delta^{34} \mathrm{~S}$ values of sulfate trending toward more positive values (Figure 9) even if the low apparent $S$ isotope fractionation factors and the large sulfate pool limits the overall enrichment of ${ }^{34} \mathrm{~S}$ in the remaining sulfate.

Categories 2 and 3 describe migration of microbial methane into favourable reductive aquifer conditions. Category 2 contains groundwater from wells \#438, \#439, \#982 and Category 3 contains groundwater from well \#456. The characteristic low sulfate concentrations of these groundwater samples can either be due to: (i) continuous BSR combined with methane oxidation along the groundwater flowpath (Category 2 with a strong ${ }^{34} \mathrm{~S}$ enrichment of the remaining sulfate due to BSR) or (ii): initially sulfate-depleted groundwater (Category 3), potentially due to the absence of pyrite oxidation. It is possible that groundwaters obtained from these wells have been subjected to a limited extent of methanogenesis. Indeed at the beginning of the geochemical 
evolution near the sulfate concentration of $10^{-3} \mathrm{~mol} / \mathrm{kgw}$ (Figures 7 and 10), the pathways between zones $2 \mathrm{a}$ and $2 \mathrm{~b}$ have not yet clearly diverged so that an attribution of groundwaters to one of the two sub-zones is ambiguous.

Category 4 comprises the groundwater samples that indicate strong evidence of methanogenesis within the aquifer. Methanogenesis is particularly obvious for groundwater from wells \#214, \#310/311 and \#333 which are characterized by a strong enrichment of ${ }^{13} \mathrm{C}$ in DIC in the groundwater samples of all three wells, with $\delta^{13} \mathrm{C}_{\mathrm{DIC}}$ as high as $+20 \%$. Groundwater form well \#991 has similar characteristics to samples from wells \#214, \#310/311 and \#333 in terms of sulfate and methane concentrations and $\delta^{34} \mathrm{~S}$ values of sulfate. However, the DIC is not as ${ }^{13} \mathrm{C}$ enriched as in groundwater from the other three wells. This may be due to additional controls on the carbon isotope ratios of DIC from other DIC sources through mixing, dilution, or water-rock interactions.

The fifth category represents the groundwater samples with low sulfate and low methane concentrations as observed in wells \#140 and \#984 (green labels, Figure 5). The low sulfate and methane concentrations can either be explained by (i) initially sulfate and methane poor waters, or (ii) groundwaters subjected to BSR leading to negligible concentrations of sulfate. Evidence of BSR from $\delta^{34} \mathrm{~S}_{\mathrm{SO} 4}$ is only visible for groundwater from well \#140. The option that these groundwater samples are also affected by a small extent of in-situ production of methane is not excluded.

\section{Conclusions and Outlook}

The geochemical and multi-isotope modeling approach developed in this study reveals two main sources of methane and the following processes affecting the obtained groundwater samples: (i) in situ methanogenesis resulting in microbial methane for a subset of samples; (ii) migration of microbial methane into aquifers with various redox conditions for a subset of samples, followed by methane oxidation coupled with bacterial sulfate reduction in sulfate-rich aquifer zones causing a pseudo-thermogenic isotopic fingerprint for the remaining methane. No evidence of thermogenic methane migrating from deep hydrocarbon reservoirs into shallow aquifers was indicated by the model.

The accurate detection of contamination of groundwater with fugitive methane, potentially associated with exploitation of conventional and unconventional energy resources, is greatly 
enhanced by the PHREEQC modeling of the interplay between methane and redox sensitive species and minerals (e.g. calcite) in the affected shallow aquifers. While designed based on the conditions encountered in groundwater in Alberta (Canada), the modeling approach is applicable to other contexts provided that adaptations are made regarding the main geochemical processes involved. Using sulfate as a key constituent for investigating Alberta groundwaters is pertinent since most groundwaters in Alberta are sulfate-rich, but in aquifers of other regions of the world sulfate may not be the dominant electron acceptor species. Other redox species such as nitrate, iron and manganese oxides may need to be considered and included in the modeling approach depending on the groundwater characteristics of the investigated aquifers. Additionally, even if some hydrochemical concepts were developed in the model to consider inflow and outflow of reactants and products, the batch calculations cannot take into account the whole complexity of groundwater movements and mixing processes at the basin scale. Despite these limitations, the model appears to be sufficiently robust to describe most of the observed chemical and isotopic compositions of the investigated groundwater samples. Hence it provides a suitable tool for decision makers for identifying the origin and fate of methane in groundwater.

Since all the geochemical processes including methane oxidation, bacterial sulfate reduction, and methanogenesis are biologically mediated, an interesting approach to improve the quality of the prediction could be a microbiological and metagenomic analysis of the groundwater samples. The characterization of the microbial communities responsible for the inferred geochemical processes would help to test whether the predicted scenarios are realistic.

For environmental impact assessment associated with the development of hydrocarbon resources from unconventional reservoirs, it is of critical importance to be able to differentiate between microbial methane formed in shallow environments, deep thermogenic methane that may have migrated into shallow aquifers, and microbial methane that has undergone oxidation. The occurrence of the latter process in shallow aquifers often results in a pseudo-thermogenic carbon isotope fingerprint of the remaining methane that can be easily misinterpreted as an intrusion of thermogenic methane from deeper zones. Differentiating these methane sources and processes solely based on concentration and isotope measurements of methane is often impossible. To resolve potential ambiguities of isotope fingerprints of methane and the associated source and process information, the model presented here uses the concentrations and isotopic compositions of methane, DIC and sulfate. Identifying and quantifying redox processes like BSR coupled to methane oxidation is crucial for determining sources and fate of methane in shallow 
groundwaters. The new modeling approach has the important capability to differentiate truly thermogenic methane from microbial methane that has undergone methane oxidation resulting in pseudo-thermogenic signatures, and hence helps to avoid misinterpretation and false-positives allegations of thermogenic gas leakage. The methodology developed in this study can be adapted and extended to other sites worldwide.

\section{Acknowledgements}

This research was conducted as part of the G-Baseline project, co-funded by the French Research Agency (ANR-14-CE05-0050 grant) and a Natural Sciences and Engineering Research Council of Canada strategic project grant (NSERC grant $\mathrm{n}^{\circ}$ 463605). Additional financial support from the Alberta Government through Alberta Environment and Parks (AEP), the Alberta Ingenuity Water Innovation Program (AI-WIP), and a NSERC discovery grant to B. Mayer is also gratefully acknowledged. We would like to thank both reviewers for their pertinent comments that helped to improve this paper.

Supplementary data

Supplementary material

\section{References}

Alberta Energy Regulator AER (2014): ST98-2014 Alberta's Energy Reserves 2013 and Supply/Demand Outlook 2014-2023.ISSN 1910-4235.May 2014.

Alberta Energy Regulator AER (2015): ST98-2015 Alberta's Energy Reserves 2014 and Supply/Demand Outlook 2015-2023.ISSN 1910-4235.June 2015

Aravena, R.; Mayer, B. (2009) Isotopes and Processes in the Nitrogen and Sulfur Cycles. In Environmental Isotopes in Biodegradation and Bioremediation; CRC Press/Lewis: Boca Raton, FL, USA, 2010; pp. 203-246,ISBN 9781566706612.

Bachu S. (2017) Analysis of gas leakage occurrence along wells in Alberta, Canada, from a GHG perspective - Gas migration outside well casing. International Journal of Greenhouse Gas Control, 61, 146-154.

Barker, J.F., Fritz, P., (1981). Carbon isotope fractionation during microbial methane oxidation. Nature 293, 289-291.

Bates, B.L., McIntosh, J.C., Lohse, K.A. and Brooks, P.D., 2011. Influence of groundwater flowpaths, residence times and nutrients on the extent of microbial methanogenesis in coal beds: Powder River Basin, USA. Chemical Geology, 284(1): 45-61. 
Bernard B. B., Brooks J. M., Sackett W. M. (1976) Natural-gas seepage in gulf of mexico. Earth and Planetary Science Letters, 31, 48-54.

Bernard B. B., Brooks J. M., Sackett W. M. (1977) A Geochemical Model For Characterization Of Hydrocarbon Gas Sources In Marine Sediments. 9th Annual Offs hore Technology Conference, Houston, Tex., May 2-5, 1977. doi:10.4043/2934-MS

Berner, R.A. (1981) New geochemical classification of sedimentary environments. Journal of Sedimentary Petrology 51,359-365.

Blanc,P., Lassin, A., Piantone, P. (2007). Thermoddem - A database devoted to waste minerals.BRGM Orleans. France, http://thermoddem.brgm.fr.

Cahill, A.G., Steelman, C.M., Forde, O., Kuloyo, O., Emil Ruff, S., Mayer, B., Ulrich Mayer, K., Strous, M., Cathryn Ryan, M., Cherry, J.A. and Parker, B.L., (2017). Mobility and persistence of methane in groundwater in a controlled-release field experiment. Nature Geoscience, 10: 289.

Carbonate Isotopes. (1991). In A. Gautschi, W. Balderer, B. E. Lehmann, A. Matter, T. Peters, H. Schmassmann \& F. J. Pearson (Eds.), Studies in Environmental Science (Vol. 43, pp. 175-237): Elsevier

Culberson, O. L., \& McKetta, J. J. (1951, August 1). Phase Equilibria in Hydrocarbon-Water Systems III The Solubility of Methane in Water at Pressures to 10,000 PSIA. Society of Petroleum Engineers. doi:10.2118/951223-G

Dawson, F., Kalkreuth,W., Sweet, A.R., (1994). Stratigraphy and coal resource potential of the Upper Cretaceous to Tertiary strata of northwestern Alberta. Geological Survey of Canada, Bulletin. 466 (60 pp.).

DiGiulio, D.C. and Jackson, R.B., (2016). Impact to Underground Sources of Drinking Water and Domestic Wells from Production Well Stimulation and Completion Practices in the Pavillion, Wyoming, Field. Environmental Science \& Technology, 50(8): 4524-4536.

Etiope, G., 2015. Natural gas seepage: the Earth's hydrocarbon degassing.

Etiope G., Schoell M. (2014) Abiotic Gas: Atypical, But Not Rare. Elements, 10, 291-296.

Etiope G., Sherwood Lollar B. (2013) Abiotic Methane on Earth. Reviews of Geophysics, 51, $276-299$.

Glasby G. P. (2006) Abiogenic origin of hydrocarbons: An historical overview. Resource Geology, 56, 8598.

Grasby, S.E., Chen, Z., Hamblin, A.P., Wozniak, P.R.J. and Sweet, A.R., (2008). Regional characterization of the Paskapoo bedrock aquifer system, southern Alberta Geological Survey of Canada Contribution 2008-0479. Canadian Journal of Earth Sciences, 45(12): 1501-1516.

Grasby, S.E., Osborn, J., Chen, Z. and Wozniak, P.R.J., (2010). Influence of till provenance on regional groundwater geochemistry. Chemical Geology, 273(3-4): 225-237.

Hamblin, A.P.. (2004). The Horseshoe Canyon Formation in Southern Alberta: Surface and subsurface stratigraphic architecture, sedimentology, and resource potential. Bulletin of the Geological Survey of Canada. 1-101. 
Hamblin, A.P., (1998). Detailed outcrop measured section of the St. Mary River Formation, Oldman River, west of Monarch, southern Alberta. Geological Survey of Canada, Open File 3613 (12 pp.).

Harkness, J.S., Darrah, T.H., Warner, N.R., Whyte, C.J., Moore, M.T., Millot, R., Kloppmann, W., Jackson, R.B. and Vengosh, A., (2017). The geochemistry of naturally occurring methane and saline groundwater in an area of unconventional shale gas development. Geochimica et Cosmochimica Acta, 208: 302-334.

Hoehler, T.M., Alperin, M.J., Albert, D.B. and Martens, C.S., (1994). Field and laboratory studies of methane oxidation in an anoxic marine sediment: Evidence for a methanogen-sulfate reducer consortium. Global Biogeochemical Cycles, 8(4): 451-463.

Huff, G.F., Woods, L., Moktan, H. and Jean, G. (2012): Geochemistry of groundwater and springwater in the Paskapoo Formation and overlying glacial drift, south-central Alberta; Energy Resources Conservation Board, ERCB/AGS Open File Report 2012-05, 58 p.

Humez, P., Mayer, B., Ing, J., Nightingale, M., Becker, V., Kingston, A., Akbilgic, O. and Taylor, S., (2016a). Occurrence and origin of methane in groundwater in Alberta (Can ada): Gas geochemical and isotopic approaches. Science of The Total Environment, 541: 1253-1268.

Humez P., Mayer B., Nightingale M., Becker V., Kingston A., Taylor S., Bayegnak G., Millot R., Kloppmann W. (2016b) Redox controls on methane formation, migration and fate in shallow aquifers. Hydrology and Earth System Sciences, 20, 2759-2777.

IUPAC-NIST (2012) Solubility Database, Version 1.1 NIST Standard Reference Database 106. Last update 2012.

Jasechko, S. and Perrone, D., (2017). Hydraulic fracturing near domestic groundwater wells. Proceedings of the National Academy of Sciences.

Kloppmann, W., Dever, L. and Edmunds, W.M., (1998). Residence time of Chalk groundwaters in the Paris Basin and the North German Basin: a geochemical approach. Applied Geochemistry, 13(5): 593-606.

Krouse H. R. (1980) Sulphur isotopes in our environment. In: Handbook of Environmental Isotope Geochemistry P. Fritz, \& J. C. Fontes (Eds.), 435-471. Amsterdam Elsevier.

Krouse H. R. (1977) Sulfur is otope studies and their role in petroleum exploration. Journal of Geochemical Exploration, 7, 189-211.

Lefebvre, R., (2017). Mechanisms leading to potential impacts of shale gas development on groundwater quality. Wiley Interdisciplinary Reviews: Water, 4(1): e1188.

Lemay, T.G. (2008) Description of the process for defining the base of groundwater protection. Energy Resource Conservation Board, ERCB/AGS Open File Report 2009-04, 27p.

Lyster, S., Andriashek, L., (2012). Geostatistical rendering of the architecture of hydrostratigraphic units within the Paskapoo Formation, Alberta. Energy Research Conservation Board, ERCB/AGS Bulletin. 66.

McAuliffe, C., (1963). Solubility in Water of C1-C9 Hydrocarbons. Nature, 200: 1092. 
McIntosh J., Hendry M. J., Ballentine C., Haszeldine R. S., Mayer B., Etiope G., Elsner M., Darrah T. H., Prinzhofer A., Osborn S. (2018) A Critical Review of State-of-the-Art and Emerging Approaches to Identify Fracking-Derived Gases and Associated Contaminants in Aquifers. Environmental science \& technology, 53, 1063-1077.

Meyboom, P. 1960: Geology and groundwater resources of the Milk River sandstone in southern Alberta, Alberta Research Council, Edmonton, Alberta, 1960.

Milkov, A.V. and Etiope, G., (2018). Revised genetic diagrams for natural gases based on a global dataset of >20,000 samples. Organic Geochemistry, 125: 109-120.

Nicot, J.-P., Larson, T., Darvari, R., Mickler, P., Slotten, M., Aldridge, J., Uhlman, K. and Costley, R., (2017). Controls on Methane Occurrences in Shallow Aquifers Overlying the Haynesville Shale Gas Field, East Texas. Groundwater, 55(4): 443-454.

Parkhurst, D.L., Appelo, C.A.J., (1999). User's guide to PHREEQC (version 2) - a computer program for speciation, reaction-path, 1D-transport, and inverse geochemical calculations. US Geol. Surv. Water Resour. Inv. Rep. 99-4259, 312.

Prinzhofer, A.A. and Huc, A.Y., (1995). Genetic and post-genetic molecular and is otopic fractionations in natural gases. Chemical Geology, 126(3): 281-290.

Prinzhofer, A. and Pernaton, É., (1997). Isotopically light methane in natural gas: bacterial imprint or diffusive fractionation? Chemical Geology, 142(3): 193-200.

Prior, G.J., Hathaway, B., Glombick, P.M., Pana, D.I., Banks, C.J., Hay, D.C., Schneider, C.L., Grobe, M., Elgr, R., Weiss, J. (2013): Bedrock Geology of Alberta; Alberta Energy Regulator; AER/AGS Map 600, scale 1:1 000 000,

Rice, A.K., Lackey, G., Proctor, J. and Singha, K., (2018). Groundwater-quality hazards of methane leakage from hydrocarbon wells: A review of observational and numerical studies and four testable hypotheses. Wiley Interdisciplinary Reviews: Water, 5(4): e1283.

Rightmire, C.T. and Hanshaw, B.B., (1973). Relationship between the carbon is otope composition of soil $\mathrm{CO} 2$ and dis solved carbonate species in groundwater. Water Resources Research, 9(4): 958-967.

Rivard, C., Lavoie, D., Lefebvre, R., Séjourné, S., Lamontagne, C. and Duchesne, M., (2014). An overview of Canadian shale gas production and environmental concerns. International Journal of Coal Geology, 126: 64-76.

Rosenthal, L., Leckie, D.A., Nadon, G.C., (1984). Depositional cycles and facies relationships within the Upper Cretaceous Wapiabi and Belly River formations of west central Alberta. Summer Field Trip Guidebook. Canadian Society of Petroleum Geologists (54pp.).

Rowe, D. and Muehlenbachs, A., (1999). Low-temperature thermal generation of hydrocarbon gases in shallow shales. Nature, 398: 61.

Schoell M. (1980) The hydrogen and carbon is otopic composition of methane from natural gases of various origins. Geochimica et Cosmochimica Acta 44, 649-661. 
Schoell M. (1983) Genetic characterization of natural gases. American Ass ociation of Petroleum Geologists Bulletin 67, 2225-2238.

Sherwood Lollar B., Frape S. K., Weise S. M., Fritz P., Macko S. A., Welhan J. A. (1993) Abiogenic methanogenes is in crystalline rocks. Geochimica et Cosmochimica Acta, 57, 5087-5097.

Tilley, B. and Muehlenbachs, K., (2011). Fingerprinting of gas contaminating groundwater and soil in a petroliferous region, Alberta, Canada. Environmental Forensics, Proceedings of the 2011 INEF Conference: $115-125$.

US Energy Information Administration (EIA). (2015). Annual energy outlook 2015 with projections to 2040 (0383(2015)). DOE-EIA, Washington D.C.

US Energy Information Administration (EIA). (2016). Annual energy outlook 2016 with projections to 2040. DOE-EIA, Washington, DC. Retrieved from https://www.eia.gov/outlooks/aeo/pdf/0383(2016).pdf

Vinson, D.S., Blair, N.E., Martini, A.M., Larter, S., Orem, W.H. and McIntosh,J.C., 2017. Microbial methane from in situ biodegradation of coal and shale: A review and reevaluation of hydrogen and carbon is otope signatures. Chemical Geology, 453: 128-145.

Whiticar, M. J. (1999). Carbon and hydrogen isotope systematics of bacterial formation and oxidation of methane. Chemical Engineering Science, 161, 291-314.

Whiticar, M. J., \& Faber, E. (1986). Methane oxidation in sediment and water column environments isotope evidence. Organic Geochemistry, 10(4-6), 759-768. doi: 10.1016/S0146-6380(86)800134

Wolfe, A.L. and Wilkin, R.T., (2017). Evidence of Sulfate-Dependent Anaerobic Methane Oxidation within an Area Impacted by Coalbed Methane-Related Gas Migration. Environmental Science \& Technology, 51(3): 1901-1909.

\section{Highlights}

- Geochemical and isotopic modeling of methane migration in groundwater (Alberta);

- Modeling in situ generation of methane in aquifers;

- Quantification of the extent of methane oxidation in groundwater;

- Modeling can assess the initial isotopic composition of methane prior to oxidation;

- No deep thermogenic methane contamination was identified in Alberta groundwater. 


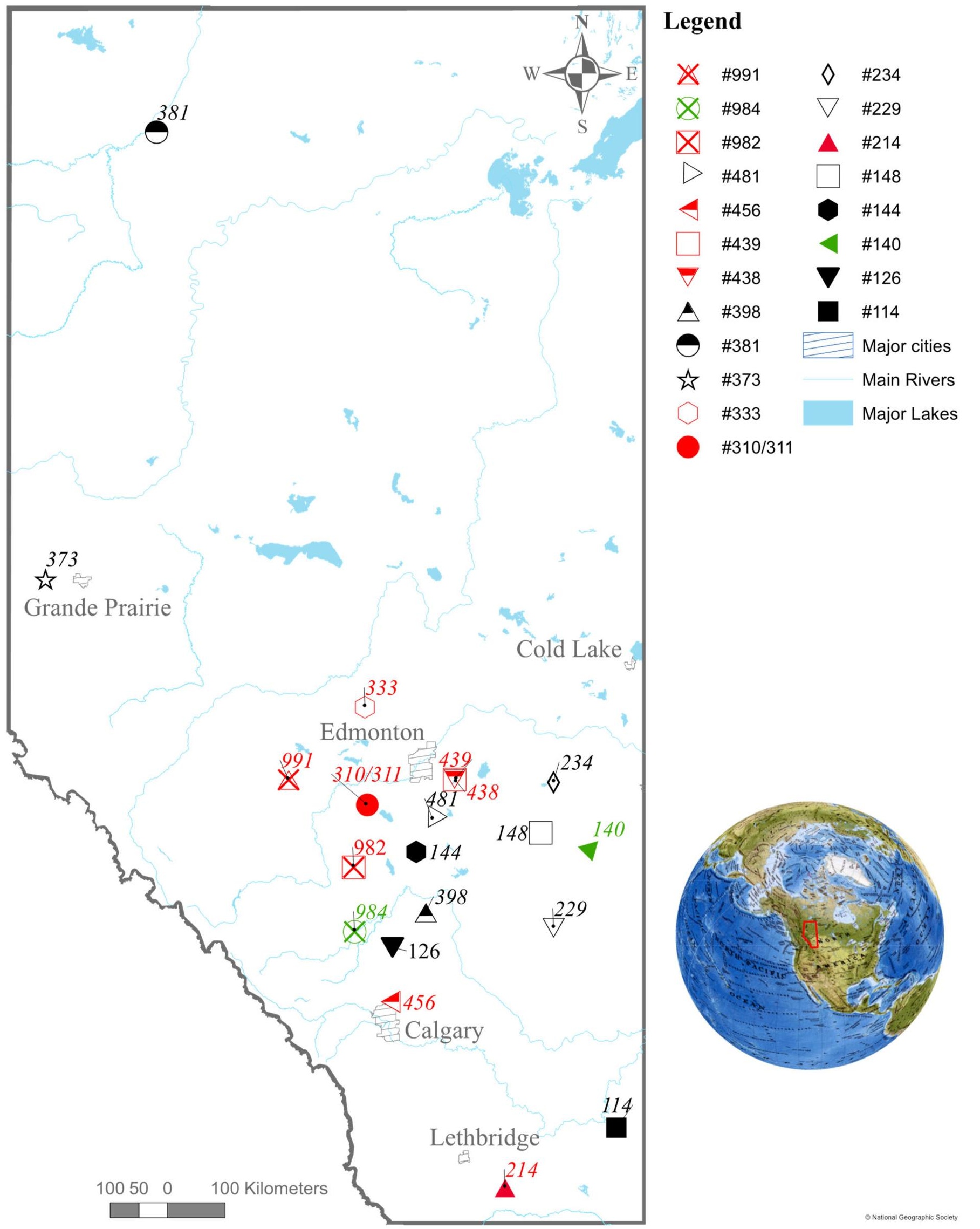



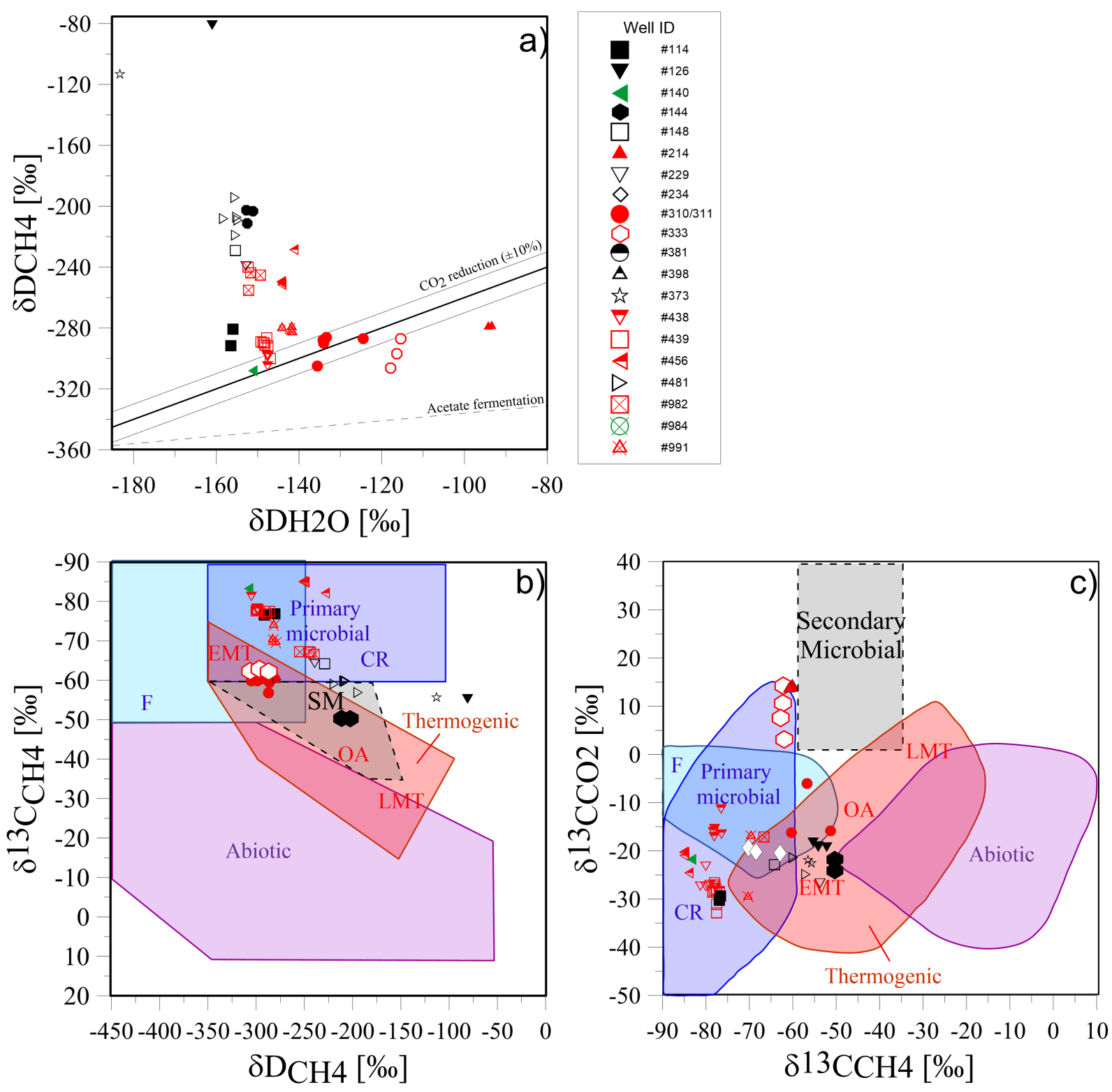

Figure 2 
Zone 1: post-oxic/ $/ \mathrm{SO}_{4}$-rich groundwater conditions

\begin{tabular}{|c|c|}
\hline $\begin{array}{l}\text { PHREEQC model hypotheses } \\
\text { - Short residence time } \\
\text { - Young/moderately old groundwater } \\
\text { - Rather fast water renewal within the aquifer } \\
-\mathrm{SO}_{4} \text { flux }>\mathrm{CH}_{4} \text { flux } \\
\text { - Large } \mathrm{SO}_{4} \text { reservoir from pyrite oxidation } \\
-\mathrm{SO}_{4}>1 \mathrm{mmol} / \mathrm{kgw} \\
-\mathrm{Na}_{\mathrm{HCO}}-\mathrm{SO}_{4} \text { water-types } \\
\text { - Unstable redox conditions for methane } \\
\text { - Equilibrium with calcite }\end{array}$ & $\begin{array}{l}\text { Geochem. \& Isotope calculations } \\
\text { Rayleigh fractionation: } \\
\delta^{13} \mathrm{C}_{\mathrm{CH} 4} ; \varepsilon^{\prime} \mathrm{CH} 4-\mathrm{CO} 2 \text { (apparent) } \\
\delta^{34} \mathrm{~S}_{\mathrm{SO} 4} ; \varepsilon_{\mathrm{H} 2 \mathrm{~S}-\mathrm{SO} 4 \text { (apparent) }}\end{array}$ \\
\hline Zone $2 \mathrm{a}: \mathrm{CH}_{4}$-rich groundwater/me & thanic conditions \\
\hline $\begin{array}{l}\text { PHREEQC model hypotheses } \\
\text { - Long residence time } \\
\text { - Older groundwater } \\
\text { - Low/negligible water renewal within the aquifer } \\
\text { - } \mathrm{Na}-\mathrm{HCO}_{3}-(\mathrm{Cl}) \text { water types due to ionic exch. } \\
\text { - } \mathrm{CH}_{4} \text { flux> } \mathrm{SO}_{4} \text { flux } \\
-\mathrm{SO}_{4}<1 \mathrm{mmol} / \mathrm{kgw} \\
\text { - } \mathrm{Stable}_{\mathrm{redox}} \text { conditions for methane } \\
\text { - Equilibrium with calcite }\end{array}$ & $\begin{array}{l}\text { Geochem. \& Isotope calculations } \\
\text { Rayleigh fractionation: } \\
\delta^{34} \mathrm{~S}_{\mathrm{SO} 4} ; \mathrm{SO}_{\mathrm{SHS}} \text { (intrinsic) } \\
\text { Isotope mass balance: } \\
\delta^{13} \mathrm{C} \mathrm{DIC} \\
\delta^{13} \mathrm{C}_{\mathrm{CH} 4}\end{array}$ \\
\hline 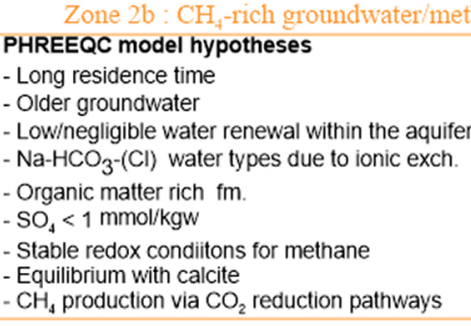 & $\begin{array}{l}\text { Geochem. \& Isotope calculations } \\
\text { Rayleigh fractionation: } \\
\delta^{34} \mathrm{~S}_{\mathrm{SO} 4} ; \varepsilon_{\mathrm{SO} 4-\mathrm{HS} \text { (intrinsic) }} \\
\text { Isotope mass balance: } \\
\delta^{13} \mathrm{C} \mathrm{DC} \\
\delta^{13} \mathrm{C}_{\mathrm{CH} 4}\end{array}$ \\
\hline
\end{tabular}

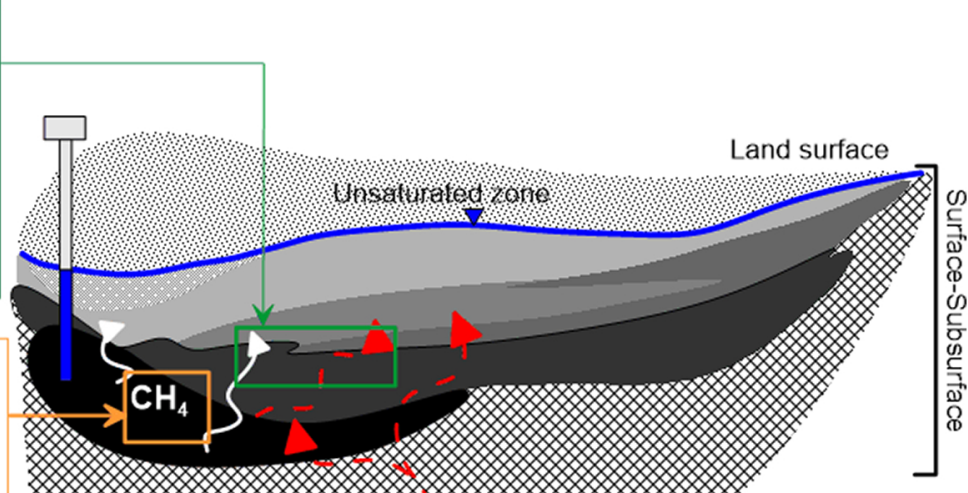

\section{.}
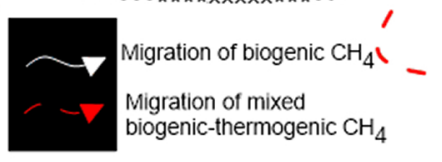

"not to scale

biogenic-thermogenic $\mathrm{CH}_{4}$

Aerobic respiration

Denitrification

[Mn(IV) reduction]

[Fe(III) reduction]

Sulfate reduction

Methanogenesis

Figure 3 


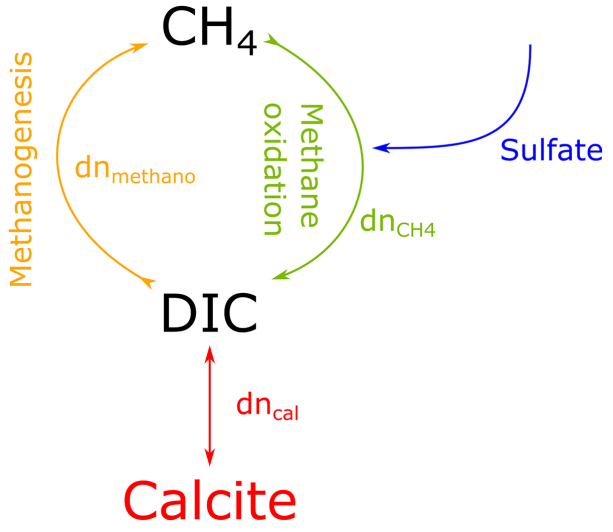

Figure 4 


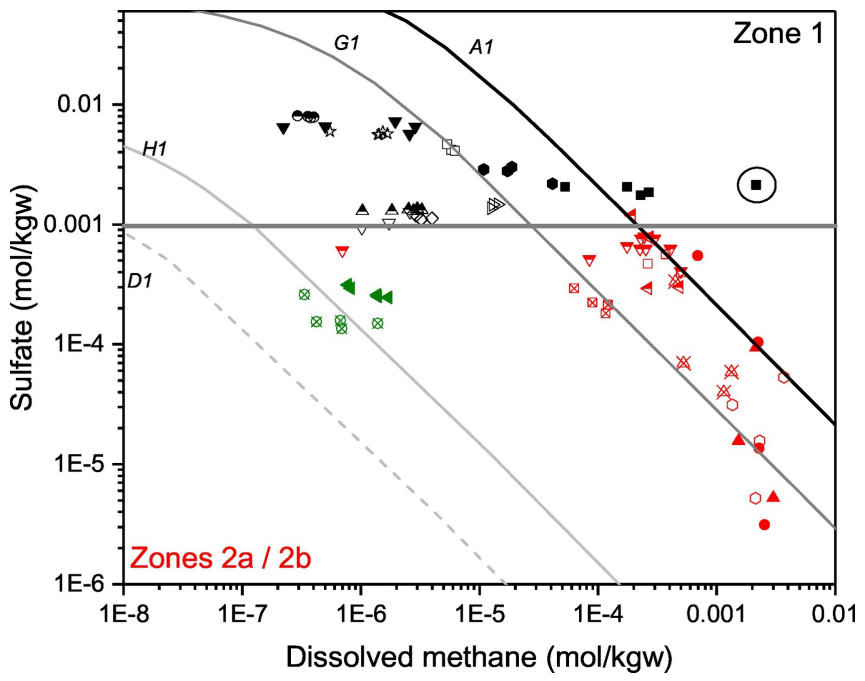

Figure 5 


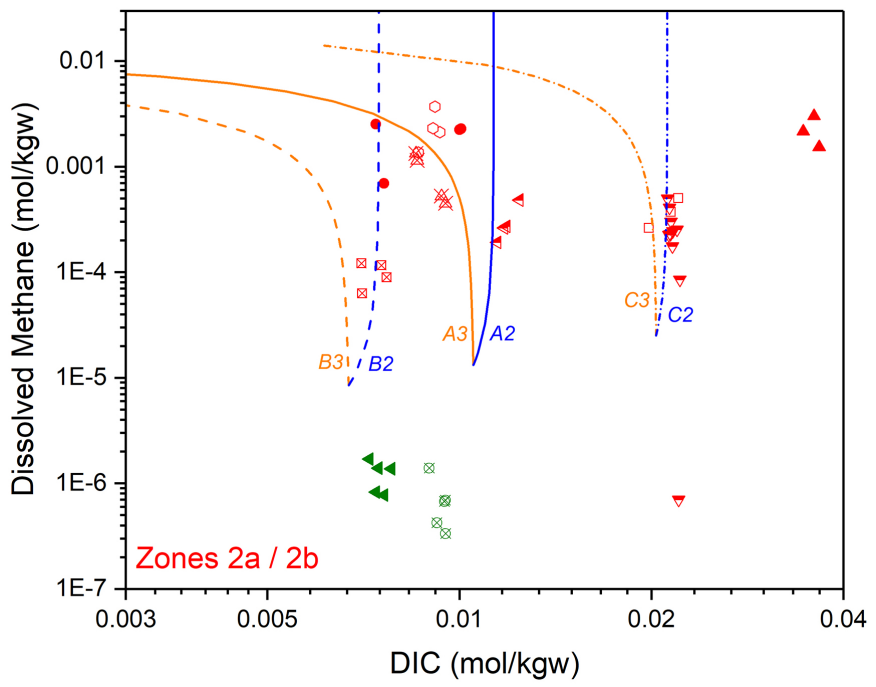

Figure 6 


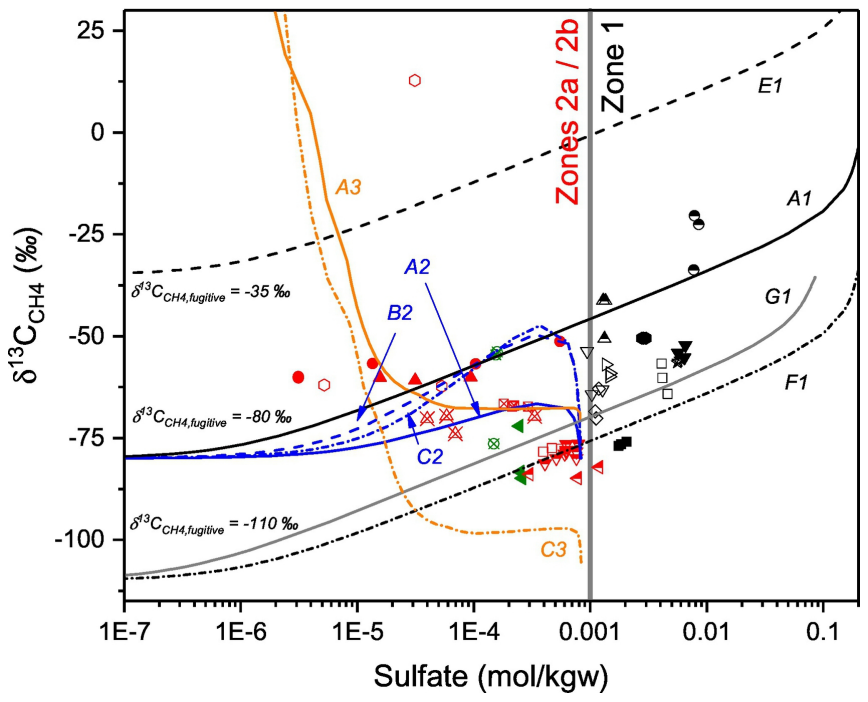

Figure 7 


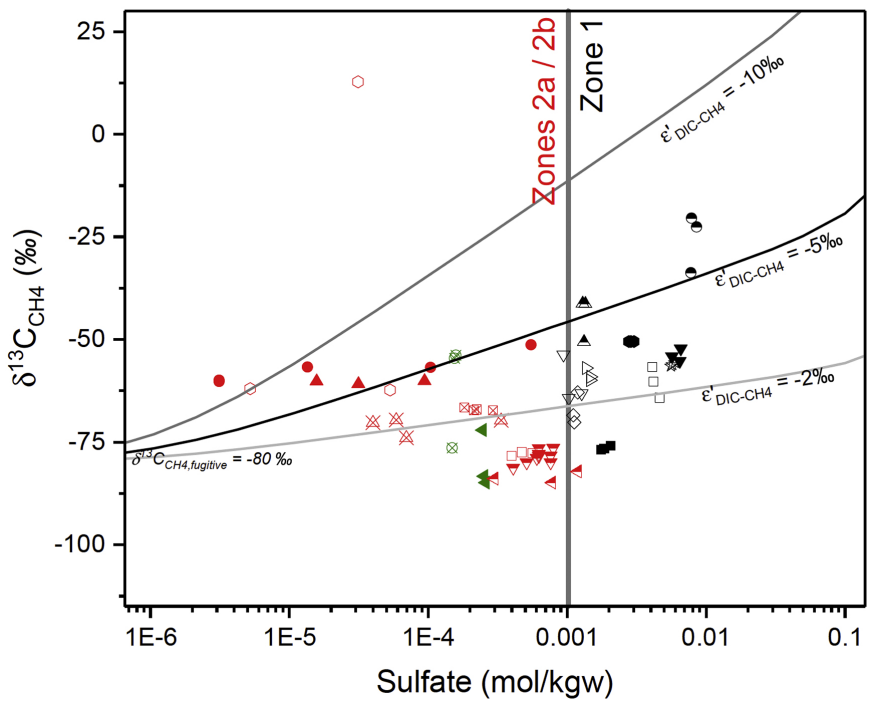

Figure 8 


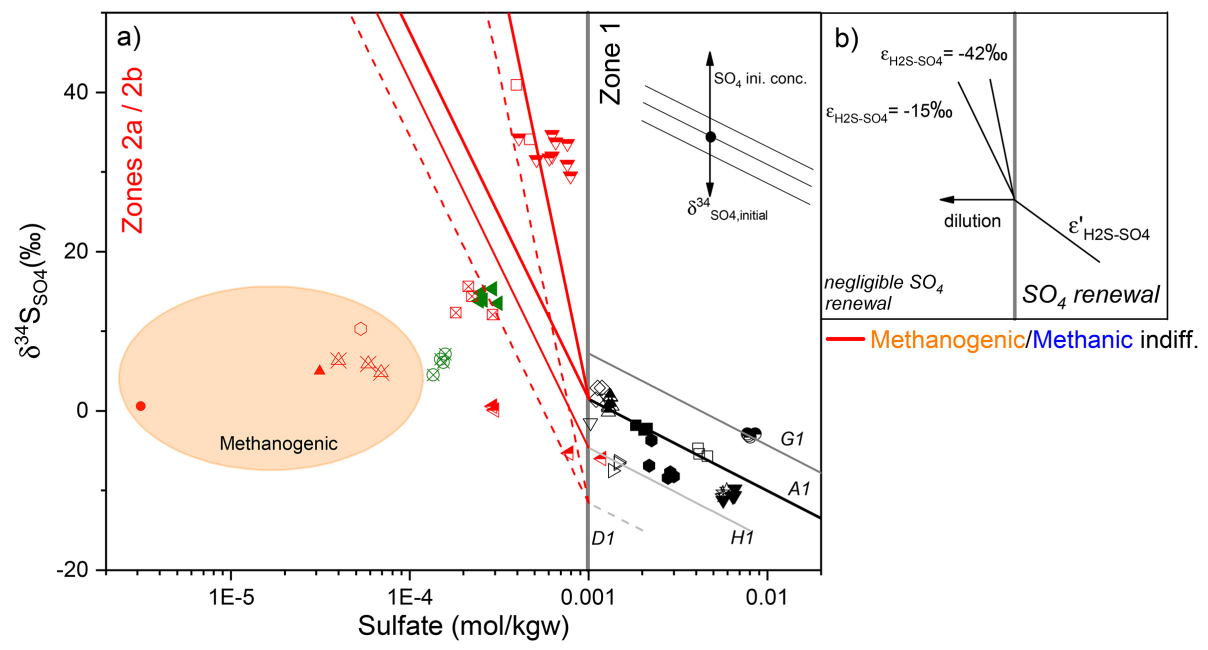

Figure 9 


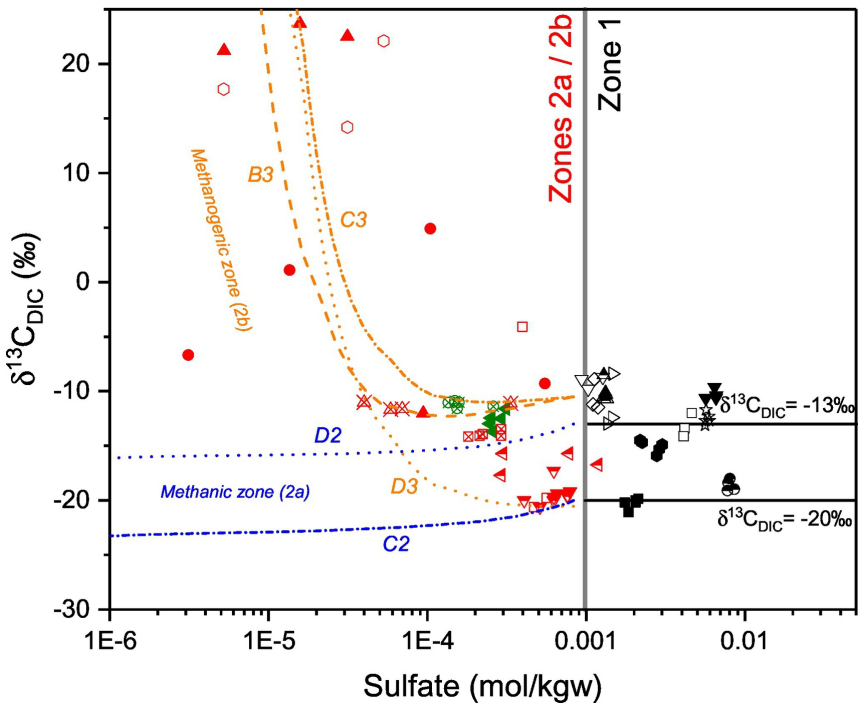

Figure 10 